Felipe Westermeyer Hernández*

Universidad de Chile

Santiago, Chile

westermeyer.felipe@gmail.com

\title{
Joaquín Fernández de Leiva: primer constitucionalista chileno de fama internacional $^{* *}$
}

\author{
Joaquin Fernández Leiva: first Chilean Constitutionalist \\ internationally renowned.
}

*Abogado, ayudante de la cátedra de historia del derecho en la Universidad de Chile, Secretario General de la Revista Chilena de Historia del Derecho.

\section{Resumen}

El autor nos presenta en perspectiva histórica biográfica a Joaquín Fernández de Leiva, uno de los diputados americanos que participó en la redacción de la Constitución de Cádiz de 1812. Tal como se advierte en el artículo, y a partir del cuidadoso estudio de las Actas de las Cortes de Cádiz, su intervención no paso inadvertida; al contrario vertió en la misma conceptos, argumentaciones y razonamientos de relevancia en el proceso de elaboración de dicha carta, situándolo sin lugar a dudas como el primer constitucionalista chileno, siendo el artículo un aporte para la historia constitucional chilena.

\section{Palabras Clave}

Constitución de Cádiz - Cortes de Cádiz - constitucionalismo gaditano - Joaquín Fernández de Leiva

\begin{abstract}
The author presents us in biographical historical perspective at Joaquín Fernández de Leiva, one of the American representatives who participated in the drafting of the Constitution of Cadiz of 1812. As noted in the article, and from of the careful study of the records of the Cortes of Cadiz, his speech did not pass unnoticed; to the contrary
\end{abstract}

**Articulo recibido el 8 de Septiembre de 2014 y aceptado para su publicación el 1 de Junio de 2015. 
it poured concepts, arguments and reasoning of relevance in the process of drafting the such founding letter, locating it without doubt as the first Chilean constitutionalist, being a contribution item for the Chilean constitutional history.

\section{Keywords}

Constitution of Cadiz - Cortes of Cadiz - Cadiz constitutionalism - Joaquín Fernández de Leiva.

Agradezco las observaciones y materiales proporcionados por los profesores Carlos Ramos Nuñez y Sergio Carrasco Delgado. Asimismo agradezco una vez más al profesor Óscar Cruz Barney por inducirme a tomar esta linea de investigación, al profesor José Luis Soberanes Fernández, por su apoyo e iniciativa para organizar encuentros destinados a debatir acerca de todo lo que significa para América la constitución de Cádiz, y al alumno colaborador de la Cátedra de Historia del Derecho del profesor Antonio Dougnac Rodríguez en la Universidad de Chile, señor Andrei Candiani. También debo reconocer la desinteresada ayuda prestada por la bibliotecaria de esa unidad académica, señora Gioconda Pulgar, quien buscó y me remitió una serie de materiales imprescindibles para realizar este trabajo. Permitaseme por último una mención especial para dos destacados profesores: don Santos Manuel Coronas González, profesor de la Universidad de Oviedo, quien, a pesar de sus actuales problemas de salud, de manera completamente desinteresada y exhibiendo una generosidad poco acostumbrada en círculos académicos, me envió por vía de correo materiales de su autoría, inéditos, a fin de poder ilustrar el contexto de esas Cortes. Mi segunda mención al profesor de la Universidad de Chile, señor Antonio Dougnac Rodríguez, quien hace ya casi 15 años me indujo a tomar como derrotero de investigación el paso del derecho indiano al patrio, y quien el año 2009 me planteó por vez primera la utilidad de estudiar al sujeto en comento. Huelga anadir que sus observaciones siempre útiles facilitaron enormemente la realización de esta investigación. Todos los errores corren por responsabilidad del autor.

\section{Introducción:}

Por razones que no es del caso traer a cuento aquí Joaquín Fernández de Leiva, Joaquín Leyva o Joaquín Leiva ${ }^{1}$ es un personaje poco conocido en su patria, Chile. No obstante,

\footnotetext{
En las fuentes consultadas recibe estos tres nombres. En la primera sesión, la de apertura, de fecha 24 se septiembre de 1810 es mencionado como Joaquín Leyva. Sin embargo, al momento de recoger los debates, todas las actas lo mencionan como Joaquín Leiva; y cuando se seńalan los integrantes de diversas comisiones es llamado Joaquín Fernández de Leiva. No obstante ser Leiva el nombre principal y Fernández sólo el patronímico usaremos en este trabajo el último nombre pues es el que ha empleado la historiografía chilena para referirse al investigado.
} 
es imposible estudiar la constitución de Cádiz y su génesis sin encontrar en las Actas de las Cortes de Cádiz una referencia a su persona. Clasificado por diversos autores como americanista, liberal y hombre de una gran erudición, sus intervenciones orientaron el debate, plantearon criterios ordenadores de las discusiones, extendieron las fronteras de lo que era posible aceptar y regular, y en más de una ocasión representó posturas que serían abiertamente minoritarias.

Prácticamente no hubo tema que se discutiese en las Cortes de Cádiz en las que el aludido, debido a su trabajo en comisión o su participación en sala, no hubiese tenido participación y conocimiento.

Joaquín Fernández de Leiva es parte y víctima de uno de los procesos más complejos que vivió todo el mundo iberoamericano y cuyas aristas hasta el día de hoy no están del todo claras. Lo que si resulta inconcuso, es que dentro del movimiento constitucionalista y codificador representa una postura que en Chile ha sido preterida tanto por la historia general como por la historiografía jurídica. El fue parte del proyecto monárquico constitucional; es decir, de la culminación jurídica de una de las formas que tomó la ilustración en Espańa e Indias a lo largo del siglo XVIII y la primera década del XIX. Dicho proyecto fue tributario de una corriente de pensamiento que quiso pasar desde el derecho y la sociedad del antiguo régimen o jurisdiccional a una de carácter más igualitario, entroncando la tradición y las creencias que atravesaban los dominios españoles de ambos lados del Atlántico y conservando alguna forma de unidad política. Representa a aquel grupo reformista que hasta última hora intentó modificar el orden existente y al mismo tiempo evitar su disgregación política. Dicho proyecto político no era afín ni con una república ni permitía afianzar la independencia política de estos países frente a una España que tardó muchísimo en aceptar el desmembramiento de su imperio. Ya hacia septiembre de 1811 los diputados americanos eran objeto de ataques y críticas provenientes de los más diversos grupos que estaban interesados en el fracaso de su labor ${ }^{2}$

Aparte de esto, es necesario considerar que esa Constitución fue percibida como un elemento más de la opresión realista y en el caso de Chile, como una imposición del virrey del Perú. Si a lo anterior se suma que -probablemente por las dificultades de comunicación y un retraso permanente de tres o cuatro meses entre la ocurrencia de los hechos y la recepción de las noticias- las cortes tomaron medidas que en la práctica desconocían el proceso reformista y/o autonomista que se llevaba a cabo en Chile ${ }^{3}$,

2 Decidor de esta situación son las críticas formuladas en un pasquín que circuló en Cádiz y que decía provenir del consulado de México. Se los acusaba de traidores y vende patria. Varios de los comisionados pensaron que el libelo era una nueva treta de los esbirros de Napoleón, interesados en atizar las diferencias entre americanos y espańoles en el seno de las Cortes. Entre los que también criticaban a ese grupo estaban los grupos más conservadores de la sociedad peninsular y los patriotas exaltados. Dicho incidente terminó con un manifiesto en que los diputados americanos de consuno exigen a las autoridades de gobierno de Cádiz un mayor resguardo de su honor y la investigación y sanción a los culpables. Diario de las Sesiones de las Cortes Generales y Extraordinarias. p. 1.886.

Como ejemplo dable es seńalar que con fecha 22 de enero de 1811 las cortes procedieron a nombrar a Manuel Vargas como dignidad de la Iglesia chilena, a Santiago Rodríguez, como canónigo de la Catedral, a Juan Rodríguez Ballesteros como Regente de la Real Audiencia, a Manuel de Salas como director de la Academia San Luis y a 
es entendible que pudiese haber alguna omisión intencional respecto al personaje investigado.

Dicho proyecto político, producto de la torpeza y ambigüedad política del monarca, no alcanzó a ver la luz, pero a nivel constitucional logró manifestarse en el papel, a través de la Constitución de Cádiz, la también llamada Pepa $a^{4}$.

Esta tuvo influjo en Chile por medios indirectos; mediante la copia casi textual, por parte de la comisión constituyente de 1822, de gran parte de su articulado. Por esa vía ejerció un rol importante aunque muy poco reconocido en la historia constitucional chilena ${ }^{5}$, conservando hasta hoy el artículo 32 de la Constitución vigente en sus números $6^{\circ}, 7^{\circ}, 8^{\circ}, 13^{\circ}$ y $14^{\circ}$ una redacción igual a la doceañista.

Desde una perspectiva dogmático-jurídica, el historiador Constitucional Luis Galdames afirma:

"En Chile la influencia de la constitución de cádiz se delata desde los primeros pasos de la organización institucional, y se prolongó durante muchos anos todavía; sin que sea ocioso afirmar desde luego que hasta la constitución definitiva de la república fue en mucha parte tomada del célebre estatuto de Cádiz ${ }^{6 "}$.

Lamentablemente el citado autor no entra a especificar en qué consiste esa influencia. Por nuestra parte podemos agregar a esta aseveración que necesario es indicar ${ }^{7}$ que la constitución de 1822 recogió de ella la teoría de la soberanía nacional, la idea de Nación; el concepto de deberes morales del ciudadano, aunque con algunas variantes; la confesionalidad del Estado; la ciudadanía; las causales de pérdida de esta; la suspensión de la calidad de ciudadano; el modo de tratar al Poder Ejecutivo; las atribuciones del poder ejecutivo; la inviolabilidad de la persona del Director Supremo; las facultades de este en cuanto jefe de las Fuerzas Armadas; el Patronato, la regulación del poder judicial; la diputación permanente de las Cortes con el nombre de Cámara del Senado; y el derecho especial para solicitar la observancia de la Constitución. La constitución de 1823; pese a tener una lógica bastante peculiar, recogió de la Pepa la regulación de la judicatura y la diputación permanente, con el nombre de Senado Conservador.

Pedro González como abogado del tribunal citado. Al momento de llegar esas providencias la Real Audiencia ya no existía.- había sido disuelta después del motín de Figueroa del $1^{\circ}$ de abril de ese año- . Por ende, aparte de ser una medida llegada de manera extemporánea implicaba un desconocimiento del movimiento juntista en Chile. Es oportuno tener presente que la Constitución de Cádiz recién ha sido justamente valorada en los últimos decenios. Su centenario no tuvo mayores ecos. Razones para explicar eso hay muchas. Probablemente una de ellas es que es el símbolo de un siglo que para Espańa fue desastroso, que fue un esfuerzo, políticamente hablando, en vano y que sirvió de foro para mostrar las diferencias entre peninsulares y americanos, siendo después tomado como base para fundamentar la emancipación política.

5 El primer trabajo que rompe esta tendencia, en cuanto a recoger todos los aspectos en que la constitución de Cádiz influyó en Chile corresponde la profesor Javier Barrientos Grandón. Barrientos Grandón (2011), pp. 674-699.

Galdames (1922), p. 287

Para un análisis detallado de estos influjos véase. "Chile y la Constitución de Cádiz: un primer acercamiento a una relación preterida”. WeSTERMEYER HeRnÁNDEZ (2012). 
La de 1828 perfeccionó las instituciones de nación, nacionalidad y ciudadanía ${ }^{8}$; la confesionalidad del estado, la cláusula territorial; suspensión y pérdida de la ciudadanía; representación proporcional de la población en el parlamento, inviolabilidad de la persona de los senadores y diputados frente a las opiniones que emitan, atribuciones del legislativo, la regulación de las municipalidades y el sistema de reforma. Por último, la de 1833 recoge de la de Cádiz la idea de un ejecutivo fuerte contrapesado por el legislativo mediante las leyes de aprobación periódica y la institución del Consejo de Estado, aunque en cuanto a la composición del último hay notorias diferencias. Además hay similitudes importantes en materia de Territorio, Nacionalidad, Ciudadanía, Nación, las restantes atribuciones del legislativo.

Relevante es también considerar que, por la manera en que la comisión redactora de la constitución de 1822 trabajó, la discusión dogmática fue mínima y las actas de la gran convención redactora de la constitución de 1833 tampoco entran a profundizar en aspectos dogmáticos en demasía ${ }^{9}$. Por ello, si se quiere entrar a conocer los fundamentos y la lógica subyacente a muchas de las normas que aparecen en las constituciones chilenas mencionadas, necesariamente debe recurrirse a las actas de las Cortes de Cádiz.

A lo anterior debemos agregar que la constitución de Cádiz es uno de los pilares del constitucionalismo moderno, aunque como texto vigente y de aplicación efectiva tuvo muy poco. Como tal, y a más de 200 años del comienzo de las constituciones escritas, importante es recordar que la gran utilidad de Cádiz es haber establecido para el mundo hispano hablante un mínimo de lo que debe tener una constitución.

Desde la perspectiva que otorga el tiempo, se debe señalar que la Constitución de Cádiz se enmarca dentro de un proceso de unificación y uniformización del derecho, cuya cara orgánica es el fortalecimiento del Estado, que comienza a absorber muchas funciones que hasta ese entonces pertenecían a las comunidades locales, jurídicamente diversas. Mediante el constitucionalismo en el área del derecho público y la codificación en el área de los derechos privado, el procesal y el penal se inicia un proceso mediante el cual las comunidades locales y las organizaciones políticas europeas de raigambre medieval pierden gran parte de su autonomía y poder en pos de un Estado fuerte y centralizado, que aglutina gran parte del poder y del derecho. En lo jurídico, este proceso se materializará en una creciente primacía de la ley como fuente formal del derecho, en una pérdida del valor normativo de la costumbre y en una nueva regulación para los tribunales de justicia y la labor del juez, con especial acento en un control de la interpretación que estos pudiesen hacer de los textos jurídicos ${ }^{10}$.

8 Acorde con lo discutido en las actas de las Sesiones de las Cortes, algunos aspectos de esas instituciones están mejor logrados en la Constitución de 1828 que en la de Cádiz. Véase Westermeyer Hernández (2012), op. cit. p. 145 y siguientes.

Para un análisis pormenorizado sobre este asunto véase WestermeYer Hernández (2014).

10 Desde esa perspectiva, las actas de las Cortes permiten conocer de primera fuente cuáles eran las principales críticas y falencias del ordenamiento jurídico vigente en Espana, del indiano y de la constitucion jurisdiccional. Muchas de las críticas que se esbozan en esas Cortes se repetirán en los 60 anos siguientes en casi todos los países de América Latina y Europa. Por lo menos en lo que respecta a Chile, las críticas que se hacen a la judicatura en 
Por esa razón es necesario hacer hincapié en que este cambio tendrá como disciplina jurídica de avanzada y vanguardia al derecho constitucional. Mediante él se materializaron las normas jurídicas que requerían las reformas planteadas por la ilustración. Será esa rama del derecho la encargada de introducir los cambios a todo el ordenamiento jurídico y desde ella se elaboraran las teorías y los raciocinios para justificar este proceso. Será también el derecho constitucional la fuente de una nueva dogmática jurídica basada primero en la libertad y luego en la igualdad y sus cultores muchas veces serán los responsables de compatibilizar esos nuevos postulados con la cultura jurídica en ese momento vigente. Por ello no es de extrañar que mucho de lo que en ese momento se llamó derecho constitucional hoy día sea derecho procesal, derecho privado, derecho penal, eclesiástico o canónico.

Por lo mismo no es exagerado afirmar que, con mayor o menor retroalimentación en los principios del constitucionalismo, el derecho constitucional de cada país refleja en esa época cuán rápido o cuán lento cada sociedad implementó los lineamientos de la ilustración. El derecho constitucional del siglo XIX podrá tener su origen en una revolución o en un proceso de reforma, se lo podrá cuestionar respecto al paradigma planteado por los juristas representativos de esa época y respecto a los modelos políticos que se levantaron como ejemplo, sea el nortamericano, el inglés o el francés; pero no se puede desconocer que cada país desarrolló un derecho constitucional acorde con su cultura política y jurídica y acorde con el nivel de desarrollo y penetración que alcanzó la ilustración. No se puede analizar el derecho constitucional del siglo XIX sin olvidar que este fue la concretización de parte importante de los postulados del siglo anterior, ni olvidar que este es el mejor espejo de la cultura jurídica y política vigente en las elites y círculos ilustrados y universitarios, ni de su capacidad para reformar la sociedad e implementar políticas públicas ${ }^{11}$.

Tampoco se puede olvidar que el siglo XVIII estuvo marcado por el despotismo ilustrado y en Europa hubo monarcas cuya pasión por esta corriente filosófica fue similar a la de sus principales teóricos. ${ }^{12}$ Por esas razones no se puede obviar que parte de este desarrollo tuvo también en América una vertiente monárquica.

Del mismo modo, justo es calificar este proceso como titánico así como la labor de los diputados doceañistas como casi increíble. En poco menos de tres años lograron sentar las bases de un nuevo proyecto político jurídico. Debieron hacer un sinnúmero de transacciones y negociaciones políticas, representar a las comunidades de las que provenían, informar las situaciones que a ellas aquejaban, buscar aliados políticos, y solucionar problemas que iban desde lo más elemental a lo más sofisticado.

Cádiz tienen una elaboración jurídica superior a las que se pueden leer.- a causa de los mismos problemas- en las memorias de los ministros de justicia para el período 1830-1860.

11 Hacemos esta distinción pues la cultura jurídica de las masas estaba en aquel tiempo mucho más ligada al decir y actuar de autoridades locales -muchas veces carentes de formación letrada-, sacerdotes, o a las prácticas gremiales como podían ser las costumbres mercantiles o campesinas.

12 Piénsese en la figura de Federico el Grande de Prusia, también conocido como Federico de Hohenzollern o en Espana en Carlos III. 
Se trató de la reunión de un grupo enorme de personas en Cortes extraordinarias, que acorde a nuestro actual léxico constitucional mejor sería llamarlas una asamblea constituyente.

Esa instancia fue la culminación del desarrollo de la ilustración en Espana y Latinoamérica. Es la culminación del trabajo de casi cuatro generaciones de intelectuales. En más de un caso, en una relacion de maestros a discípulos, ellos comenzaron a cuestionar el orden existente primero desde la enciclopedia y los nuevos conocimientos en materia de ciencias naturales; para luego pasar a una crítica de las estructuras jurídicas y económicas de la sociedad y sus consecuencias para el desarrollo individual del hombre al alero de la razón; de esa crítica se pasó a otra de carácter literario, finalizando con la generación dedicada a la política y al derecho constitucional, cuya mejor personificación es Agustín Argüelles ${ }^{13}$.

En este contexto, nos proponemos indagar la labor del jurista Joaquín Fernández de Leiva en las mentadas Cortes. Son muchas las preguntas que, dada la escasa sistematización sobre su rol como jurista y legislador, aún no tienen respuesta. ¿Qué acervo jurídico traía desde Chile? ¿Cuáles fueron sus ejes argumentativos? ¿Cuáles eran las ideas jurídicas en boga en Chile en ese momento? ¿Qué intereses tenía la clase dirigente santiaguina y cómo Fernández de Leiva trató de defenderlos? ¿Qué papel jugó en la articulación del cambio de sistema jurídico en las Cortes de Cádiz? ¿Podríamos aventurar que el criterio jurídico de este diputado doceańista pudo en algún aspecto precaver cuán difícil sería la implementación en América Latina de este sistema? ¿Se corresponden las ideas expuestas por Fernández de Leiva con las vigentes en Chile en aquellos ańos? Dar una respuesta a estas preguntas requeriría un esfuerzo de investigación y elucubración que excede por mucho a este trabajo; pero creemos que una adecuada sistematización de sus intervenciones puede ser determinante para iluminar aquellas áreas de la cultura jurídica de la primera década del siglo XIX que aún están en un claroscuro. También nos proponemos dar a conocer algunas de las ideas que el exhibió en ese foro. Probablemente este artículo no llene las expectativas de los cultores del derecho público; pues mucho de lo que hay acá no alcanza a ser definido ni conceptualizado claramente de acuerdo a lo que hoy se entiende por derecho constitucional. A lo más acá hay elementos para entender como éste fue formando en base al ensayo y el error. Tampoco dejará contentos a los que sostienen una visión maniquea y dual del proceso independentista o de emancipación política, ni a los que vinculan dicho proceso per se con un determinado sistema de gobierno; pues, si bien el proyecto en el que Fernández de Leiva tomó parte desde un punto de vista político fue un fracaso, no deja por ello de ser indicativo de la variedad de ideas constitucionales que también hubo en el valle central de Chile. No todos pensaron en la República de inmediato.

Probablemente la necesidad de citar otros textos de relieve en ese momento y comparar los postulados defendidos en Cádiz por el chileno con los primeros textos de índole

13 El profesor Manuel Santos Coronas González en sus materiales inéditos la sintetiza con la secuencia: Feijoo, Campomanes, Jovellanos y Argüelles. 
jurídico y político que circularon en Chile en esos años hará que este texto parezca farragoso. Desgraciadamente es difícil encontrar otro método para poder contrastar adecuadamente tales ideas. Por último y por la poca discusión que hubo al adoptar subrepticiamente la Constitución de Cádiz como un modelo para el constitucionalismo en Chile es que también nos ha parecido interesante ahondar en los puntos de vista que Fernández de Leiva adoptó; pues está fuera de discusión que el texto gaditano demandó mucho más trabajo que la redacción de cualquiera de los textos constitucionales que ordenaron la vida del valle central de Chile durante el siglo XIX. Aparte de este objetivo, pretendemos cumplir por medio de este artículo otros bastante más modestos: contribuir a mostrar otras facetas de tan complejo proceso, la existencia de otros proyectos políticos y recrear la cultura jurídica vigente en ese momento en Chile por medio del hombre que mayor contacto con otros políticos y juristas relevantes de su época tuvo.

\section{Datos Biográficos:}

Sobre el personaje en estudio se ha escrito muy poco en Chile y se lo ha citado mucho en el extranjero. Gran parte de esas citas tienen relación con el estudio de los ejes temáticos que esa asamblea constituyente discutió. Sus intervenciones en el pleno fueron alrededor de cincuenta. Desgraciadamente no hay datos que permitan saber cómo sesionaron las comisiones; pero es presumible que en ellas haya hecho un mayor uso de la palabra; pues en varias ocasiones fue el encargado de exponer en el plenario el trabajo de la comisión y sus conclusiones. En algunas de ellos incluso lo hizo haciendo saber al pleno su desacuerdo con la forma en que la comisión de turno resolvió un tema, criticando la solución acordada y dando luego a conocer su propia propuesta. En comparación con la gran mayoría de los diputados hizo un uso reiterado de la palabra en el pleno, aunque no al nivel de un Argüelles o un José Mejías. Ellas destacaban por su profundidad y extensión.

Entre los estudiosos que citan a este chileno, sólo a modo de ejemplo baste mencionar a José Sánchez-Arcilla Bernal ${ }^{14}$, y Rafael Estrada Michel ${ }^{15}$. Ambos autores citan a Fernández de Leiva a propósito del estudio del rol de los diputados de la Nueva Espana. -el primero- y a raíz de las discusiones por una mejor forma de representación de los americanos en parlamento y acerca de la nueva organización gubernamental que las Indias requerían para un mejor gobierno el segundo. En particular el último autor destaca el sentido de oportunidad y solidez de los argumentos jurídicos presentados por el diputado chileno.

14 Sánchez-Arcilla Bernal (1988), pp. 961-987. En ella el autor menciona a Fernández de Leiva acorde con los distintos partidos que en el transcurso de las Cortes los diputados asumieron.

15 Estrada Michel (2010). El autor lo cita en varias ocasiones a raíz de discusiones que para objeto de su trabajo eran relevantes, poniéndolo como una de las cabezas pensantes entre los americanos. 
Mención aparte merece un artículo de reciente publicación del profesor José María Porras Ramírez, quien en el encabezado dedica su estudio a este chileno, en aras de su defensa de un proyecto constitucional americano ${ }^{16}$. Casi todos los trabajos que lo mencionan dicen relación con el estudio de alguno de los ejes temáticos que se desarrollaron en las Cortes, citando a Fernández de Leiva como un representante del grupo americano y exponiendo cuál era su postura. La inmensa mayoría de ellas destaca que el chileno centraba sus intervenciones en aspectos estrictamente jurídicos. Su aporte político fue muy bien matizado con argumentos de índole estrictamente jurídico o de corte filosófico-jurídico.

Aparte de ello aparece mencionado en una serie de páginas webs que tratan sobre los diputados doceanistas; sin embargo casi todas ellas se limitan a repetir datos ya conocidos referentes a su formación universitaria, su árbol genealógico y las comisiones en las que se desempenó. Practicamente todos los sitios disponibles en internet recogen la información de los cortos estudios de Enrique Matta Vial ${ }^{17}$, Ramón Rozas ${ }^{18}$ y Elías García Huidobro $^{19}$. Esas tres publicaciones tienen el mérito de dar a conocer al personaje en cuestión, revelar documentos que ni siquiera el historiador Diego Barros Arana habría visto y reproducir algunos de sus discursos. Lamentablemente ninguna de esas publicaciones valora al personaje en cuestión en su dimensión histórica ni muestran las particularidades de su labor. No entregan información alguna acerca de la relevancia de su actuar, ni tampoco acerca de la importancia del proceso en el que tomó parte. Ninguno de esos trabajos despierta interés desde un punto de vista histórico jurídico. Tampoco se acercan a Fernandez de Leiva con la perspectiva de un proceso de transformación y cambio. Por el contrario, los tres estudios citados centran la atención en los ya rescatados aspectos biográficos y familiares, tales como quiénes eran sus medios hermanos, los blasones nobiliarios de su padre, su rol como docente universitario y los títulos habilitantes con los que viajó a la península. Se puede aventurar que esos tres estudios están empapados de una lógica maniquea y dual del proceso de emancipación política. España y la monarquía representaban la oscuridad y la opresión y la independencia la libertad y el progreso.

Paradójico resulta que mucho antes de que los mentados autores chilenos se acercasen a esta figura, uno de los hombres más relevantes de España en el siglo XIX, el diputado por Asturias José María Queipo de Llano, más conocido como el Conde de Toreno ${ }^{20}$,

\footnotetext{
Porras Ramírez (2013).

MatTa Vial (1920), pp. 307-340. Ese artículo luego fue transformado en un libro.

Rozas (1885), p. 32 y siguientes.

García Huidobro (1912), pp.330-361.

De acuerdo a los trabajos inéditos del profesor Manuel Santos Coronas, el Conde de Toreno fue uno de los principales representantes del movimiento liberal y constitucionalista en Cádiz. Oriundo de Asturias y miembro de una de las familias más poderosas de Espana, fue uno de los diplomáticos encargados de viajar a Inglaterra durante la guerra contra Napoleón a solicitar armas y dinero. Regresado de esos menesteres resultó electo diputado por Asturias para integrar las Cortes de Cádiz. En ese contexto, destacó por estar entre los reformistas y apoyar a Argüelles en la confección de un nuevo pacto político para la península y demás reinos que integraban la Corona. Su modelo era la monarquía inglesa. Su visión era que la nación era la única detentataria del poder constituyente, por lo que a toda costa había que restringir las facultades del rey, por medio de una ampliación de las facultades
} 
ya puso de relieve la importancia histórica del chileno en cuestión. Con pluma lacónica y moderada en los epítetos ilustró cuán importante fue Fernández de Leiva en ese proceso. Así es como lo incluye dentro de los diputados americanos que el considera "sabios, elocuentes y de ameno decir." En su opinión el más destacado era José Mejías y entre los que le apoyaban estaban Leiva, Morales Duarez y Feliún ${ }^{21}$. Lo sitúa entre los liberales ${ }^{22}$; es decir, aquellos que constantemente usaban la expresión: "de acuerdo a los principios liberales" 23 .

Siendo el Conde de Toreno uno de los protagonistas y luego estudioso de ese proceso, su opinión es de estudio obligado para quien quiera acercarse al constitucionalismo gaditano. El valor de la obra del Conde de Toreno es enorme en razón de ser su libro abajo citado una mezcla del género de las memorias con el cultivo historiográfico. Vivenció ese proceso y luego tuvo la oportunidad de criticarlo y rememorarlo con la experiencia dada por una vida entera dedicado al servicio público, la divulgación del liberalismo y la política. Como ya se ha dicho, el trabajo en las Cortes fue intenso, y las fuentes escritas alcanzan a revelar sólo una parte de lo acaecido. Hay otra, la del diario vivir, de las negociaciones, de los conciliábulos de pasillo, de las intrigas, de las maquinaciones, de las envidias y rivalidades personales que las actas de las Cortes evidentemente no pueden reflejar. A ello se debe añadir que la experiencia de participar tanto de la oposición como del gobierno le dio la oportunidad de ponderar de mejor manera a quienes eran realmente un aporte en el debate público.

En resumen, con pocas palabras el citado político hispano fue quien, al alero de su prestigio y calidad de testigo y protagonista, por primera vez puso de manifiesto la importancia del chileno en cuanto jurista y partícipe de esa asamblea constituyente.

Más de un siglo debió pasar desde la publicación del libro del Conde de Toreno hasta que se produciese una revaloración de la constitución de Cádiz. En ese contexto es

\footnotetext{
e las cortes, órgano que representaba a la nación. Según el profesor Joaquín Varela Suanzes-Carpegna, luego de un corto exilio en Londres, tuvo la oportunidad de tomar contacto en Paris con lo más selecto del liberalismo postnapoleónico. Dicha experiencia le habría permitido adoptar las ideas de Bentham, la teoría constitucional de Constant y el positivismo sociológico de Comte. Tal experiencia lo transforma en un liberal moderado, cuyo objetivo en materia de derecho constitucional pasa a ser una monarquía integradora, a fin de darle estabilidad al nuevo sistema político. A su vuelta a España se dedicó a la política. En opinión del citado académico, representa claramente los límites del liberalismo español. SANTos Coronas (2004).

21 Conde De Toreno (1872), p. 304

22 El hecho que José María Queipo de Llano califique a Fernández de Leiva como liberal tiene un significado que va mucho más allá de lo que se puede estudiar en este artículo. El mentado Conde fue el más joven de los diputados gaditanos y también conocido como uno de los liberales más exaltados. Ese liberalismo se manifestó tanto en sus discursos como en su posterior trayectoria pública, que lo obligó en más de una ocasión a partir al exilio. Fue un buen representante del liberalismo europeo y en Espana, con posterioridad a las guerras napoleónicas destacaría por su furibundo impetú en pos de la desamortización de los bienes de los regulares. Por ende, no se puede poner en duda qué, si no alcanza a representar las corrientes más ortodoxas del liberalismo europeo de la primera mitad del siglo XIX, si por lo menos es un buen representante de la forma en que esa doctrina fue entendida y aceptada en Espana. Por ello, que Toreno califique a este chileno de reformista y liberal muestra cuán de avanzada eran sus posiciones entre los constituyentes.

23 Importante es esta aclaración pues las Cortes de Cádiz representan un liberalismo aún tímido y no del todo desarrollado, en relación a lo que será esa corriente en la segunda mitad del siglo XIX y a la leyenda que con posterioridad se tejió sobre ese proyecto político.
} 
mucho lo que se ha escrito al respecto en las últimas décadas. Dentro de ese cúmulo de investigaciones resulta también de consulta obligada el libro de María Teresa Berruezo: "La participación Americana en las Cortes de Cádiz"24. Dicha obra sistematiza el rol de cada uno de los diputados que tomó parte en esa Asamblea. Sobre Fernández de Leiva senala: "Su actividad en las Cortes fue intensa y muy destacada....en un gran número de discusiones debió dar su parecer" ${ }^{25}$ Luego de ese comentario la autora hace una relación de sus principales intervenciones realzando en que los principios rectores de ellas fueron la defensa de las libertades del hombre, la división de los poderes del Estado y la monarquía constituciona ${ }^{26}$. Agrega que sus intervenciones fueron vistas por muchos como peligrosas, sin embargo ella lo considera un antiindependentista ${ }^{27}$.

En base al reconocimiento dado por uno de los protagonistas de esa época y luego por una destacada estudiosa insistimos en que no deja de ser paradójico que la historiografía tradicional, la historia del derecho y el derecho constitucional hayan olvidado su persona casi por completo.

Un primer acercamiento hacia sus ideas fue hecho por Jaime Eyzaquirre en su ya clásico libro "Ideario y ruta de la emancipación chilena", dónde reivindica el discurso igualitario y tradicionalista del estudiado en dichas cortes ${ }^{28}$. En ese mismo sentido el historiador Walter Hanisch lo menciona entre los hombres públicos de Chile que representaron una construcción ideológica al momento de iniciarse el proceso emancipatorio. Su análisis es sin embargo escueto y con un acento mucho más filosófico que jurídico ${ }^{29}$. Hanisch lo tilda de hombre de ideas populistas, pues no creía en la monarquía de derecho divino sino en la versión pactista inspirada en el ideario de San Isidoro de Sevilla.

Dicha preterición en definitiva fue rota hace poco por la historiadora Paula Caffarena Barcenilla, quien ahonda en su rol como diputado gaditano, plantenado la necesidad de superar las categorías dicotómicas para interpretar el proceso emancipatorio. Sin lugar a dudas ese artículo es lo más elaborado respecto a su rol como diputado gaditano que hasta el momento se ha escrito en Chile ${ }^{30}$.

Sobre su persona se puede indicar que nació hacia $1775^{31}$ y fueron sus padres el español Lucas Fernández de Leiva, comerciante avecindado en Chile y María Loreto Erdoiza y

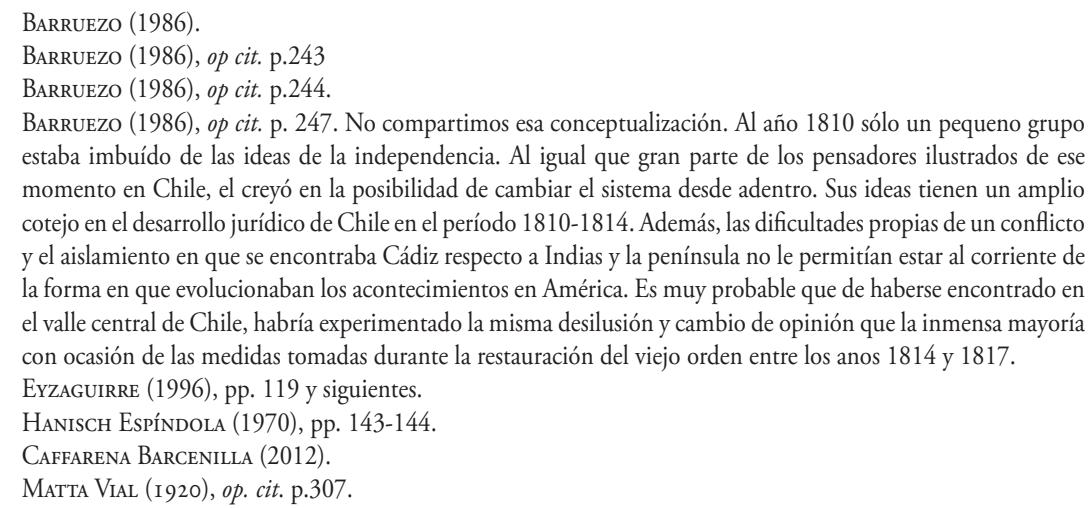


Aguirre. Por vía materna era medio hermano del guerrillero y héroe de la guerra de la independencia Manuel Rodríguez Erdoiza, del magistrado Carlos Rodríguez Erdoíza y de Ambrosio Rodríguez Erdoiza.

Ingresó a estudiar derecho a la Real Universidad de San Felipe, dónde obtuvo el título de Doctor en Leyes y Cánones: Su tesis doctoral se tituló: "Los justos derechos con que la Corona de España domina las dos Américas"32. Ella versó sobre el proceso de conquista española. En virtud de ese trabajo fue admitido profesor en esa casa de estudios en noviembre de 1799. En esa Universidad desempeñó el cargo de Consiliario Mayor, y ejerció el de rector en calidad de suplente.

Ingresó el año 1797 a la Real Academia Carolina de Leyes, de la que llegó a ser presidente. Como profesor universitario fomentó el estudio del derecho, pagando con su propio pecunio un premio a la mejor investigación anual en Derecho Real, Civil o de Gentes $^{33}$. Su vida universitaria y académica la realizó por completo en la Real Universidad de San Felipe. Con los antecedentes proporcionados por el Conde de Toreno se puede afirmar que Fernández de Leiva corresponde a una generación instruída en América, que fue capaz de asumir la conducción política y el gobierno de sus países. Ricardo Levene describe esa generación como el producto de la educación universitaria en América: "Las Universidades de Indias fueron centros irradiantes del saber donde se formaron las generaciones que lucharon por la independencia y la libertad"34.

Recibió el título de abogado el año 1800, desempeñándose en la Real Audiencia, en el Cabildo eclesiástico y el secular, en la Junta de Vacuna y siendo designado uno de los cuatro asesores letrados del Tribunal de Minería, del que pasa a ser diputado general el año $1808^{35}$.

Cómo diputado doceañista integró las comisiones ${ }^{36}$ de estudio de la divulgación del decreto de convocatoria a las Cortes Generales y Extraordinarias; la de justicia ${ }^{37}$, la de examinación de la lista de empleos provistos por los diversos ministerios ${ }^{38}$, la de

32 Berruezo (1986), op cit. p.241.

33 García Huidobro (I9I2), op. cit., pp. 340-341.

34 LeVEne (1956), p.129

35 La relevancia de este organismo y una mención detallada de todos los que en él desempenaron funciones se puede encontrar en el artículo de Dougnac RodRíGuez (1999), pp. 111-158.

36 Las cortes se organizaron de tal manera que todo el que pedía la palabra tenía derecho a hablar en las sesiones plenarias. Así se buscaba fomentar la participación y reflejar de la mejor manera la voluntad de la nación. A fin de compatibilizar esa función con un trabajo más expedito se crearon una serie de comisiones, las que debían cumplir con distintos roles y en las que los diputados que estaban en posición mayoritaria hablaban por medio de su dictamen, que en cada ocasión debía ser expuesto al resto de los diputados por un comisionado. Los que estaban en una posición minoritaria debían fundamentar su postura haciendo uso de la palabra en las sesiones plenarias. Por tal motivo a poco andar el trabajo de la comisión se fue perfeccionando y especializando. Indicativo de la calidad en cuánto político y jurista es el número de intervenciones que cada diputado realizó en el plenario y la cantidad de comisiones que integró.

37 Cortes Generales (1810 - 1813), p.23.

38 Cortes Generales $(1810$ - 1813), op cit. p.78 
haciend $\mathrm{a}^{39}$, la responsable de la redacción de un proyecto de ley que asegure la libertad de los ciudadanos ${ }^{40}$, y la encargada de redactar la constitución ${ }^{41}$.

Destacó también desde un principio por promover acuerdos y medidas destinadas a ayudar a todos los grupos insurgentes y solucionar el caos administrativo reinante ${ }^{42}$.

Como diputado los ejes de su labor fueron la reforma de la legislación vigente, la formación de un nuevo orden constitucional, la mantención del imperio español como unidad política y el respeto y compromiso por el derecho. Su calidad de profesor universitario queda de manifiesto mediante una serie de reformas legislación castellana e indiana y el rescate que hizo en las sesiones plenarias de los aspectos de la cultura jurídica indiana que se correspondían con los deseos de reforma. Muestra lo anterior la crítica que formula al Consejo de Regencia por su actuar. Le recuerda que en el derecho indiano todas las autoridades están sometidas al imperio de la ley, todas sus actuaciones están reguladas por la norma y por ello la arbitrariedad en América no es posible. Asimismo exige a las cortes tener presente que el Rey de Espańa siempre se jactó de ser un fiel observante de la legislación, valor jurídico que los constituyentes gaditanos debían recoger y conservar ${ }^{43}$.

Tras casi 20 meses de arduo trabajo como constituyente y legislador, el aludido presentó su renuncia el 16 de febrero de 1812, siendo informada al pleno el 31 de marzo de $1812^{44}$. Problemas económicos lo llevaron a renunciar para ocupar un cargo como alcalde del crimen en la Audiencia de Lima ${ }^{45}$, haciendo previamente una escala en Chile. Sabía que su labor como diputado doceañista quedaba inconclusa; pero también, al igual que muchos otros diputados, entendió que parte de la legitimidad de su labor descansaba en la probidad y en la independencia en el ejercicio de sus funciones. Fue un fiel seguidor de uno de los principios que orientaron a los miembros de esa asamblea constituyente: "renunciar a toda fortuna personal... La confianza que la nación tiene en nosotros se acreditará con el voto público y solemne de huir hasta de la tentación de acordarnos de nuestras propias personas, para no despojar a la virtud del nombre de austeridad, que debe ser en nosotros su divisa"46. Tal principio recibió sanción legal mediante un decreto que prohibía aceptar cualquier empleo, ayuda o pensión mientras durase el cargo que los diputados detentaban. La aplicación estricta de aquel reglamento significó que muchos de los diputados que participaron en la inauguración de estas cortes prefirieron jugar un buen papel mientras tuvieron los medios y cuando

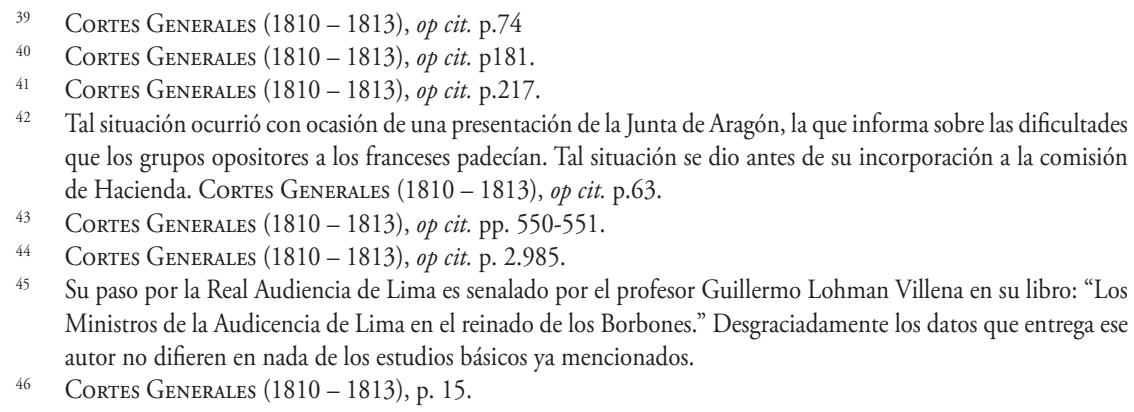

45 Su paso por la Real Audiencia de Lima es senalado por el profesor Guillermo Lohman Villena en su libro: "Los Ministros de la Audicencia de Lima en el reinado de los Borbones." Desgraciadamente los datos que entrega ese autor no difieren en nada de los estudios básicos ya mencionados.

46 Cortes Generales (1810 - 1813), p. 15. 
estos se acabaron, renunciar en lugar de caer en tratativas que los llevaran a perder su independencia y eventualmente su buen nombre. Fernández de Leiva no cuenta entre los primeros que debió aceptar esa solución. Desgraciadamente murió al poco tiempo de su renuncia, en 1814, sin poder ver ni el rol que sus medios hermanos jugaron en la guerra de la independencia ni como juristas en los albores del período republicano ni tampoco como terminaría un proceso social del que fue parte activa.

\section{III. ¿Representante de Chile en las Cortes de Cádiz?}

Para determinar si Fernández de Leiva actuó como representante del Reino de Chile ante las Cortes no nos quedaremos en el ya clásico enunciado acerca de su calidad de diputado suplente, sino que indagaremos brevemente en las ideas jurídicas acerca de representación política en ese momento vigentes en Chile; en los intereses de los criollos y la elite gobernante; en los conflictos sociales que atravesaban la sociedad chilena y los documentos que lo habilitaron para viajar a Espańa.

Sobre las ideas, importante es señalar que a nivel latinoamericano la ilustración, en su versión católica, no era una tendencia desconocida. El interés por la educación y la instrucción de la masa, el trabajo conjunto entre la Iglesia y el Estado en pos de una mejor educación del pueblo; una mayor libertad de comercio y un mayor espacio para la iniciativa privada, mediante una modernización del aparato estatal; la necesidad de un uso racional de los recursos económicos; un rol activo del Estado en la defensa y promoción de los intereses nacionales y políticas proteccionistas que permitiesen la adquisición de ventajas comparativas en materia de industria y capital humano, y la instrucción de oficios útiles, eran parte de los objetivos de la sociedad chilena de ese entonces ${ }^{47}$. Por esa razón ya se habían formulado proyectos tendientes a reformar el sistema tributario, derogar algunos monopolios e instaurar un sistema de libre comercio dentro de los reinos de la Corona ${ }^{48}$. Para concretizar esas ideas el aparato gubernamental buscó el apoyo de gremios y grupos de interés. Es así como surgen las Sociedades Económicas de Amigos del País ${ }^{49}$ y se da un nuevo impulso a la justicia corporativa.

Paralelamente, a partir del estudio de la obra de Campomanes, se inicia un fuerte cuestionamiento al sistema de propiedad de la tierra. El cuestionamiento a la Mesta, las manos muertas, los mayorazgos y otras limitaciones a la circulación de la propiedad pasan a formar parte de los temas frecuentes entre grupos ilustrados con interés en el conocimiento y buen funcionamiento de la economía.

No todas estas ideas lograron una materialización jurídica durante el período indiano. Muchas de ellas serán obra de los nuevos Estados. Sólo a modo de ejemplo considé-

47 Probablemente el mejor representante de estas ideas era Manuel de Salas, cuya vida se abocó por completo a materializar las ideas citadas.

48 Véase a este respecto. Levene (1956), op cit. pp.59 y siguientes.

49 LeVene (1956), op cit. p.66. 
rese que desde las primeras medidas de liberalización del comercio adoptadas el año 1720 hasta la dictación del Reglamento y Aranceles Reales para el comercio libre en España e Indias", en $1776^{50}$ transcurrió más de medio siglo. Esa apertura nunca fue completa y las autoridades reales en muchas ocasiones cedieron ante los grupos de presión locales. En consecuencia lo que hubo fue una liberalización muy asimétrica, atizando las pugnas entre los grupos económicos locales.

Tales pugnas, debido a la política de cooptación entre las elites locales y la burocracia indiana, arrastraron a las autoridades locales. En Chile tal situación sucedió a raíz del comercio de trigo con Perú. Los trigueros chilenos se quejaron de estar en una situación de permanente desventaja producto de las restricciones decretadas por el virreinato para internar a Chile ciertos productos ${ }^{51}$. Tal fenómeno fue el catalizador de un naciente protonacionalismo. Surgió un sentimiento de pertenencia colectiva, identificado con el lugar de residencia, tendiente a satisfacer las necesidades y aspiraciones sociales. Ese sentimiento contó con el apoyo que las autoridades locales le dieron a las diversas solicitudes que las comunidades presentaron ante el poder central, fuese este el virreinato o el rey ${ }^{52}$.

No obstante esa nueva conflictividad, dichas políticas económicas significaron un auge que permitió que las sociedades americanas también se abocasen al ocio creador. A pesar de la distancia con Espana, las ansias de superación las llevaron a solicitar la creación de universidades. En Chile tal tarea correspondió al cabildo de Santiago, que a su costa terminó asumiendo los costos que implicaba semejante proyecto educativo. Las generaciones que llevaron adelante la independencia se formaron en esas nuevas casas de estudio. En Chile ese honor correspondió a la Real Universidad de San Felipe ${ }^{53}$.

En lo jurídico, las propuestas de reforma al sistema político de la monarquía hispana abundaron en la segunda mitad del siglo XVIII. Más de una de esas propuestas iba encaminada a una nueva forma de entender la monarquía, moderándola por medio de reformas que la transformasen en una de carácter constitucional, en que el poder del Rey estuviese contrapesado por el de una asamblea de representantes elegidos por los ciudadanos de cada provincia, acercándola a los territorios americanos. Dichas ideas partían por entender que el Rey es un trabajo más y como tal su detentario debía cumplir con una serie de requisitos ${ }^{54}$.

En materia política, desde la conquista se fue conformando un núcleo dirigente formado por los descendientes de los primeros conquistadores. Ese grupo gozó de un estatuto especial, consistente en derechos otorgados por el Rey y convertidos luego en costumbre. La mantención de esas prerrogativas fue defendida por los descendientes mediante la impugnación en tribunales de toda medida gubernamental que se considerase lesiva de

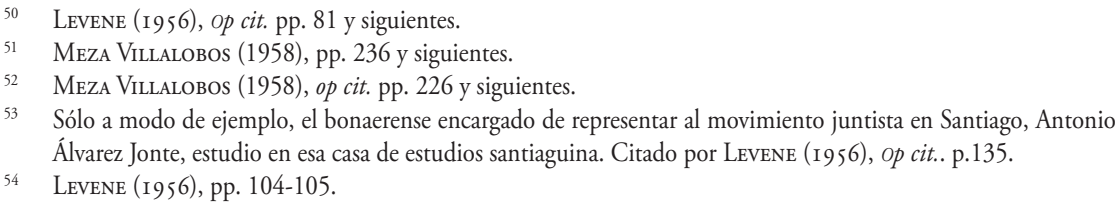


tales derechos. Tal práctica marcó la discusión ante la Real Audiencia de Santiago a lo largo del siglo XVII ${ }^{55}$. A comienzos del siglo XVIII ya era observable un fuerte espíritu de grupo dentro de la clase dirigente. Ese grupo aprendió en el siglo XVII que por medio de los recursos dados por el ordenamiento jurídico podía paralizar la labor de cualquier gobierno. Los gobernadores ilustrados sabían aquello y estaban plenamente concientes que el nuevo paradigma de gobierno implicaba ceder cuotas de poder a los grupos locales, si es que efectivamente querían hacer carrera como funcionarios imperiales. En los hechos, ellos emplearon diversas formas de cooptación o cogobierno con algunas de las familias poderorosas. Es así como el gobernador Manso terminó cogobernando con el grupo identificado como descendiente de los conquistadores y Amat y Junient buscó el apoyo de aquellos que se dedicaban al comercio. Aunque cada uno se apoyó en grupos distintos, de ahí en adelante el gobernador no podía actuar sin el apoyo y la confianza de los nacionales. En esos grupos el origen era determinante. Por ello el nacimiento en una familia de la clase dirigente era requisito sine qua non para gozar de los beneficios y honores que el aparato estatal y la administración indiana prodigaban a los nacionales ${ }^{56}$.

Esa idea de privilegio por descendencia junto a la política adoptada por los gobernadores trajo aparejadas tensiones que se catalizaron en la resistencia a la llegada de advenedizos. -preferentemente espańoles- y en la necesidad de un mayor grado de autonomía de la elite local.

Esa necesidad de autodeterminación fue encauzada a través de la formulación de nuevas políticas y la participación en nuevas instituciones. Por ese mismo tiempo, el Cabildo de Santiago fue recuperado por los criollos y se transformó en la institución representativa de sus intereses. Paradojicamente, el nuevo desenvolvimiento de las relaciones políticas sólo vino a exacerbar el interés en participar activamente del gobierno y ser parte de las nuevas instituciones.

Tales equilibrios políticos fueron puestos en entredicho con ocasión de la invasión napoleónica. Las noticias acerca de la renuncia de Fernando VII implicaron que el cabildo comenzase a hacer uso y abuso del derecho de petición a las autoridades. Él se encargó de organizar una eventual defensa del reino y un correo permanente con Buenos Aires. La torpeza y ambigüedad del gobernador y el temor a una invasión permitieron durante algunos meses que las decisiones más relevantes pasaran por manos del Cabildo de Santiago y el grupo que en el estaba representado ${ }^{57}$. La citada corporación propuso medidas administrativas y tributarias tendientes a defender el territorio y fortalecer el Estado, al mismo tiempo que juraba lealtad al rey cautivo ${ }^{58}$.

55 Una larga relación de esos conflictos, la manera en que se gestaron y como fueron resueltos se puede leer en MEZA Villalobos (1958).

56 Meza Villalobos (1958), op. cit. p.249.

57 Meza Villalobos (1956), pp.35 y siguientes.

58 Meza Villalobos (1956), op cit. pp. 46-53. 
Tal situación fue vista con malos ojos por la burocracia imperial y por los afines a la causa realista. Temerosos de perder el poder o precaviendo una posible emancipación, optaron por no acoger ninguna de las peticiones solicitadas por el cabildo. El secretismo con que las autoridades indianas enfrentaron hechos de la trascendencia como la apertura y respuesta a la carta de la princesa Carlota Joaquina ${ }^{59}$, ilustra cómo se llegó al estado de alarma y división del año 1810 .

Ese sentimiento de exclusión y la creciente desconfianza entre criollos y realistas motivó al cabildo a nombrar un apoderado que lo representase ante el Consejo de Regencia ${ }^{60}$. Dicha comisión recayó en el investigado.

Dicho acuerdo, de fecha 2 de diciembre de 1808, fue titulado nombramiento de apoderado en la Corte y lo habilita para representar ante "Su Majestad" la lealtad, amor y obediencia de Chile; dándole plenos poderes para intervenir y representar al Cabildo en todos los asuntos que este tenía pendientes ante la Corte, revocando cualquier poder otorgado por esa corporación con anterioridad y autorizándolo para solicitar todas las medidas y reformas necesarias para un mejor desenvolvimiento del reino ${ }^{61}$.

Acorde con el desenvolvimiento de los hechos en lo sucesivo, estimamos que ese documento debe interpretarse en conjunto con el informe en derecho emitido por el Procurador General José Miguel Infante el 14 de agosto de $1810^{62}$, que si bien es motivado por una situación particular ${ }^{63}$, muestra cuánto habían evolucionado las ideas políticas y cuál era la interpretación acerca del rol del cabildo desde el inicio de la crisis política. En ella Infante, haciendo alusión a la ley III, capítulo 15 de la Partida II, fundamentó que ante la ausencia de un monarca legítimo el poder se encontraba nuevamente en el pueblo ${ }^{64}$ y las leyes emanaban únicamente de la soberanía, cuyo titular había vuelto a ser este. Por esa razón cada regidor del cabildo se veía constituido en un padre de la patria y todos reunidos tenían la potestad misma del pueblo, cuya misión era gobernar para conservar los derechos del rey y el reino. En ausencia de este, los mayores de la patria, los hombres ricos y nobles, jurando la honra y guarda de su señor y el bien común de la patria, debían elegir a los hombres que los representen. Infante exhibe una buena opinión sobre la Junta Central Gubernativa, constituída en septiembre de 1808; no así del Consejo de Regencia, ya que considera que este recibió

59 Hija de Carlos IV, reina de Portugal y emperatriz honoraria de Brasil, no eran pocos los que pensaban que en base a su relación parental con Fernando VII podría asumir desde Brasil el gobierno de los reinos que integraban la Corona espanola. La senal política que dio el gobernador alimentaba sospechas de una ruptura con el monarca y/o la desesperanza de que este pudiese volver.

60 Dicho acuerdo fue suscrito por lo más granado de la sociedad santuiaguina de ese momento. Entre los firmantes cuentan, entre otros, Pedro Díaz de Valdés. Ignacio de la Carrera, José Antonio de Rojas, Manuel de Salas, Bernardo de Vera, José Rodríguez Zorrilla y Juan Enrique Rosales.

${ }^{61}$ Texto disponible emn el sitio web www.historia.uchile.cl Fuentes documentales y bibliográficas para el estudio de la historia de Chile.

62 Texto completo disponible en el sitio web www.historia.uchile.cl

63 Tal dictamen fue emitido con ocasión del juramento de reconocimiento al Consejo de Regencia.

64 En este caso se entiende la voz pueblo sólo como la reunión de las personas cuyas virtudes las hacen merecedoras de derechos de carácter político. 
el poder de parte de la primera en una situación de temor, por lo que en su opinión esa transmisión adolecería de vicio de nulidad.

De acuerdo a la opinión de Infante, al estar la monarquía descabezada, el poder había vuelto al pueblo y este, como sujeto titular de la potestad constituyente, estaba representado a través del cabildo. De acuerdo a ese documento, los actos de la Junta serían válidos, no así los del Consejo de Regencia. Estos adolecían de vicio de nulidad. Fernández viajó con el encargo de representar la postura del Cabildo de Santiago en la Corte. Al momento de otorgarsele el mandato el monarca ya estaba cautivo. Ese mandato y el encargo en el contenido emanaron de los vecinos representados en el cabildo. Todos los firmantes eran considerados en Chile hombres ricos y nobles. Acorde con esas ideas, Fernández de Leiva era un representante del soberano pueblo de Chile. El mandato que se le confirió fue amplio, atendida la posibilidad de un rápido cambio de las circunstancias, razón por la cual no se puede descartar la posibilidad de interpretar, acorde con esas ideas, que entre las posibilidades estuviese una Corte extraordinaria.

Lo anterior no quiere decir que ambos documentos juntos lo habilitaban como detentatario de una potestad constituyente en las Cortes, al menos no en los términos en que hoy día se entiende dicha potestad. A pesar de sus amplias facultades, para ser diputado titular, la regulación otorgada exigía un mandato que en términos formales y explícitos habilitase para tomar parte en las cortes de Cádiz. Él no lo tenía. Los términos en que las Cortes regularon la participación non estaban concebidos en términos indianos. Empero tampoco vale considerarlo como un diputado suplente más, recogido en Cádiz para tal objeto sólo por el hecho de encontrarse en ese momento en esa localidad o en sus alrededores ${ }^{65}$. Fernández de Leiva viajó a España con una misión de carácter político ${ }^{66}$. Acorde con las ideas indicadas y el procedimiento que se usó para llenar los cupos faltantes, Fernández de Leiva fue más que un mero diputado suplente. Chile, por medio del cabildo de Santiago ${ }^{67}$, lo envió a España a cumplir una misión política y a promover la adopción de medidas que beneficiasen a Chile. Producto de las circunstancias tuvo la oportunidad de participar en una asamblea constituyente,

65 Hacemos este comentario pues el otro diputado chileno, Miguel Riesco, vivía al momento de la instalación de las Cortes en Cádiz hacía largo tiempo y sus actividades eran exclusivamente de carácter privado. El se encontró ante un cometido de esa índole por azar.

${ }_{66}$ Este punto de vista no es compartido por todos. De hecho, la profesora Berruezo indica que los motivos de su viaje a Espańa son controvertidos. Por una parte está Luis Galdames, quien sostiene que ese viaje tuvo como fundamento los documentos acá citados. Por otro lado, José Toribio Medina cree que el viaje a Espańa obedecía a motivos enteresamente privados, cuales serían resolver asuntos de derecho sucesorio de su padre y abuelo. Por nuestra parte compartimos la tesis de Luis Galdames. El mandato del cabildo habla por sí solo. A mayor abundamiento véase BERRUEzo (1986), op cit. p.242.

67 Importante es destacar que en muchos aspectos la representación política de todo el reino descansaba en la corporación municipal santiaguina. Eso puede parecer extrańo en el conjunto de los cabildos latinaomericanos. Por ello requiere una precisión. En Chile también se dio el fenómeno que cada Cabildo era autónomo para ejercer el derecho de petición ante el monarca; sin embargo, producto de la guerra de Arauco y la consiguiente destrucción de gran parte de las ciudades de Chile al sur del Biobio a fines del siglo XVI y la pobreza de las restantes, el derecho a tomar el juramento a las nuevas autoridades recayó sólo en el cabildo de Santiago. Ya a comienzos del siglo XVII diversos documentos reconocen implícitamente esta realidad, al denominar a Santiago como "Cabeza de Gobernación". Con el tiempo dicha realidad de hecho se transformó en una costumbre. Para mayores antecedentes, véase MeZa Villalobos (1958), pp. 40 y siguientes. 
que intentó materializar los anhelos y proyectos tanto tiempo esperados en esta parte del mundo. Su designación no fue obra del albur.

Distinto es que, acorde con el vertiginoso ritmo de los acontecimientos y el creciente grado de incertidumbre, con posterioridad el Cabildo de Santiago se negase ha participar del proceso constituyente. Tal situación se debió al hecho de considerar que uno o dos diputados era muy poco e implicaba ceder ante una nueva institucionalidad con la que las relaciones no estaban aen buen pie. Si a eso se suma que tal acto validaba la nueva organización y las noticias que llegaban desde la península ibérica hablaban de una posible derrota militar, es entendible que se rehusasen a participar. Era mejor asegurar lo que ya había logrado el movimiento juntista en Chile.

Las labores encomendadas a los diputados decían relación con el apoyo a la institucionalidad hispana levantada en la emergencia. Pero eso no significó que perdiese la oportunidad de reivindicar los intereses de Chile o del grupo que representaba. En este aspecto la situación más relevante en la que tuvo participación fue en los debates por las subdelegaciones.

Una vez que entre los constituyentes hubo consenso acerca de las diferencias entre América y España, se instituyó una comisión especial de "Negocios Ultramarinos", cuya competencia alcanzaba todos los asuntos de gobierno y legislación relacionados con América y las Filipinas. Ella tuvo presente las repetidas quejas llegadas desde la ciudad de Arequipa por el deficiente funcionamiento de la institucionalidad indiana. Los habitantes de esa región elevaron una queja porque los jueces no fallaban de acuerdo las leyes de indias, no se cumplían los plazos legales de detentación de los cargos y que muchos no podían ejercer sus derechos debido a la carestía de los trámites procesales. La justicia en Los Andes resultaba cara. Fernández aprovechó ${ }^{68}$ la ocasión para solicitar que se derogasen las delegaciones en el reino de Chile y que sus funciones recayesen en los alcaldes ordinarios del cabildo. Fundó su petición en deficiencias en la ordenanza de intendentes y en que las dudas acerca de la implementación de esa institucionalidad no fueron subsanadas con las reformas del año $1803^{69}$, en la poca oportunidad política de aquella medida y en la dudosa juridicidad de la medida por parte del Consejo de Regencia, organismo que de haber estado seguro de esa medida no estaría buscando además la venia de las Cortes $^{70}$. El período del cargo duraba seis ańos, el designado podía ser letrado, militar o miembro de la Oficina de Real Hacienda y contemplaba funciones de administración y jurisdiccionales. Implicaba una gran concentración de poder. Es parte de la institucionalidad que los Borbones le dieron a América, concebida para quitarle poder a los gobiernos locales y dárselo al Estado.

${ }_{68}$ En la Corte había especial ciudado con mantener contentos a los habitantes de Perú y Alto Perú, pues el recuerdo de la rebelión de Tupac Amaru estaba muy vivo y uno de los diputados doceañistas suplentes por Perú era descendiente de un linaje incásico: Dionisio Inca Yupangui. Este destacó por sus elocuentes intervenciones tendientes a reivindicar la calidad y actual civilización del amerindio, por mostrar una imagen muy negativa del proceso de conquista del Perú y por calificar dicho proceso como una usurpación. Fue enemigo de la mantención de las castas, advirtiendo que los excluídos podían convertirse en enemigos de la Corona.

69 Cortes Generales (1810 - 1813), p.1393.

70 Cortes Generales $(1810-1813)$, op cit. p.1401. 
Las subdelegaciones implicaban una fuerte reducción de la autonomía local y la odiosa llegada de españoles a posiciones de poder en la burocracia indiana. Su establecimiento; no obstante favorecer una mayor profesionalización de la judicatura, provocó fuertes reparos en toda América pues su énfasis era antes que nada de carácter tributario. La expansión del Estado hizo necesaria una mayor recaudación de impuestos ${ }^{71}$. En Chile las subdelegaciones no se habían establecido aún por ser nulo el aporte tributario de este país al fisco.

Fernández estaba en una posición absolutamente minoritaria y debió hacerse cargo de críticas tales como que "en Chile no se admiten empleados designados por el Gobierno"72. Él defendió el actuar del gobierno en base al reconocimiento al Consejo de Regencia que había hecho la junta chilena y en base a un decreto emitido por el primer Consejo de Regencia con fecha 30 de abril de 1810, en que se señalaba que el gobierno patriota y leal al monarca no designaría empleo alguno para las Indias ${ }^{73}$.

\section{Igualdad, representación, ciudadanía y virtud: una nueva constelación para diferenciar a las personas}

La igualdad fue desde el primer momento el canto de sirena con el que Napoleón intentó seducir a los reinos americanos ${ }^{74}$. Ofrecer la igualdad como aquello que los habitantes de este lado del Atlántico anhelaban y la Corona española no les había dado. Entre los diputados había muchos que querían mayor igualdad; pero esta era de por si algo muy díficil de determinar. Su materialización y especificación causaría muchísimos problemas. ¿Sería una igualdad política de carácter numérico a la hora de elegir a los representantes para las Cortes? ¿Qué principios o conceptos determinarían quienes son los iguales y quienes los desiguales? ¿Cuál sería la justificación para un trato desigual? ¿Introducir la ciudadanía era reconocer que los miembros de las castas en que estaba agrupada la población americana dejarían de serlo por obra de una nueva constitución? ¿Cómo contener las nuevas expectativas a fin de no destruir el tejido social existente?

En este punto, las cortes no tenían modelo alguno por el cual orientarse. Las constituciones de Francia y Estados Unidos fueron concebidas para poblaciones más homogéneas y para regir territorios relativamente pequeños.

71 Una interesante descripción de esta institución y del fenómeno político que llevaba apararejada puede encontrarse en Alcauter GuZmán (2012).

Ibid.

Ibid.

Bonaparte pretendía mediante esa concesión neutralizar cualquier apoyo monetario de los reinos americanos al movimiento juntista hispano. La invasión napoleónica significó el desdibujamiento de la política de alianzas entre las distintas casas reinantes europeas. Desde el término de la guerra de la sucesión Espana y Francia desarrollaron estrechos vínculos diplomáticos. Con ocasión de la deposición del monarca España se ve forzada a iniciar tratativas políticas con Inglaterra. Esta última no estaba en condiciones de financiar una guerra en la península ibérica. De ahí la importancia que toman los reinos americanos. De su apoyo económico dependería el éxito o fracaso de la guerra contra Napoleón Bonaparte. 
El principio de la igualdad y la determinación de quienes serían ciudadanos sería una de las tareas más difíciles desde un punto de vista dogmático-jurídico y político que las Cortes deberían enfrentar. Más aun este nuevo discurso, si se quería conservar la unidad de los reinos que componían la Corona, no se podía articular sino sobre conceptos que convencieran a todos los habitantes de los territorios de habla hispana.

Por otra parte, no debe olvidarse que desde un principio hubo conciencia en las Cortes acerca de la necesidad de apaciguar aguas en América. Se tenía certeza acerca de la existencia de movimientos emancipadores en distintas regiones y, en el seno de las Cortes la desconfianza y el recelo entre americanos y peninsulares no eran menores.

Los diputados americanos manifestaron desde un principio su interés en una reforma dentro del sistema. Unidad y reforma constitucional constituían las dos bases inamovibles de su labor en Cádiz. Por eso hicieron presente ya en la segunda sesión de trabajo de las cortes que no era adecuado publicar en América los decretos de convocatoria sin alguna declaración destinada especialmente a los americanos. La idea era diseñar una convocatoria que fuese lo más inclusiva posible. Para ello se formó inmediatamente una comisión destinada a proponer la mejor forma de informar en América acerca de la instalación de las cortes ${ }^{75}$. Entre los designados estaba el jurista chileno.

Los diputados integrantes entendieron que esa comisión era la oportunidad perfecta para instalar el tema de las necesidades de los reinos americanos y exigir un nuevo trato entre ellos y la península ibérica. Para ello hicieron un petitorio de tres puntos: reconocimiento de la igualdad de derechos entre los españoles europeos y los americanos; otorgamiento de la representación nacional como parte integrante de la monarquía y dictación de una ley de amnistía que favoreciese a todos aquellos que en ese momento tomaban parte en grupos insurgentes o sufrían la persecución por parte del aparato burocrático indiano en aras de sus ideas, posiciones políticas o cargos que detentaban ${ }^{76}$.

Tal propuesta derivó en el llamado decreto del 15 de octubre, que hizo un reconocimiento a la igualdad entre los súbditos de España, América y Filipinas. Este decreto se transformaría en el trascurso de las sesiones en el fundamento de toda la discusión sobre igualdad y representación ${ }^{77}$.

La implementación de los principios que dicho acto jurídico administrativo contenía encauzó las diferencias entre peninsulares y americanos. Ella permitió traslucir todos y cada uno de los temores y prejuicios existentes hacia América y su gente y también puso de relieve cuán complejo sería aplicar ese principio en una sociedad hasta ese momento

\footnotetext{
Cortes Generales (1810 - 1813), p.6.

Cortes Generales (1810 - 1813), op cit. p.6.

Si bien en la sesión en que fue discutido y aprobado las actas no acompañan el texto de la citada pieza jurídica, los actas posteriores recogen un texto que creemos fidedigno: "España y América es una misma cosa; una misma monarquía, una misma y sola Nación, una misma y sola familia e iguales en todo los naturales de ambos hemisferios, unos y otros acreedores a la protección de V.M., así como obligados a desprenderse d cuanto tienen hasta de su misma y preciosa sangre, por salvar a la patria."
} 
regida y acostumbrada a un sistema de castas. Los americanos querían igualdad en la diferencia; el problema es que las cortes nunca tuvieron claro qué aspectos autorizaban un trato desigual y cuáles eran a esos efectos intrascendentes. Se podría decir que todos querían igualdad en la diferencia. Todos querían un estatuto de privilegios respecto al resto. La gran dificultad fue como fundamentar esas peticiones. Mientras los peninsulares fundaron sus peticiones en su mayor homogeneidad racial y cultural y en ser los mejores representantes de la tradición hispana, los americanos exigían un trato especial en razón de la discriminación y la posición jurídica desventajosa que tenían al momento de poder optar a un cargo en la burocracia imperial; a que ellos no eran acreedores de las mismas facilidades que los peninsulares cuando querían viajar y trabajar en la península y que las políticas económicas favorecían a España en desmedro de América. Unos querían ese estatuto como un privilegio por ser la cuna de la nación española y considerarse por ello su mejor representante y otros como una compensación por su postergación histórica.

Ambos grupos optaron por postergar la discusión hasta el tercer mes de trabajo. Sabían que la necesidad de una mejor elaboración conceptual requeriría de un tiempo enorme. Cada vez que ese tema se discutía las cortes se transformaban en un polvorín. Esta discusión comenzó por una bagatela. Se propusó destinar dos horas diarias de las sesiones públicas a discutir el reglamento provisional del Consejo de Regencia, idea aceptada por los peninsulares y que no fue aceptada por los americanos. Mientras los últimos querían esas dos horas para América y sus problemas los peninsulares las querían para modificar la legislación ${ }^{78}$. En los días siguientes cualquier incidente era aprovechado por los americanos para hacer valer la premura de sus necesidades y las de sus territorios. Es así como con ocasión de la presentación de una memoria sobre la reorganización de la defensa de los territorios situados en el río Paraguay y en la costa oriental del Río de la Plata Fernández de Leiva dijo: "las proposiciones que hemos hecho los diputados americanos son generales y no deben retardarse" 79 .

Había conciencia que un mal manejo de ese debate podía significar la ruptura del cimiento de ese nuevo orden estatal: la Nación. Era importante conservar los afectos y no perder el sentido de la unidad, mientras se ganaban posiciones dentro del nuevo pacto político. La primera estrategia para evitar entrar en esa discusión fue apelar a un mejor trato para el aborigen. Con ese fin se emitieron declaraciones y decretos mandando a las autoridades reales en América a cautelar el buen trato hacia el aborigen, sus privilegios y libertad personal, protegerlo y evangelizarlo acorde lo disponía la legislación española. Hubo decretos especiales en que mandaban a los párrocos dedicar las homilías de las misas a ese fin. Con ello se buscaba allegar a esos grupos étnicos a España e impedir que distintos sectores sociales interesados en la emancipación política pudiesen aliarse.

Zanjado este tema, se entendió que la manera de hacer efectiva esa igualdad, acorde con las ideas sobre soberanía nacional era por medio de la adecuada representación en

Cortes Generales (1810 - 1813), p. 283.

Cortes Generales (1810 - 1813), op cit. p. 297 
las Cortes. Dado el imaginario jurídico existente, dicha aseveración no mereció ningún reparo; no obstante ser una institución con muy diversos significados en el derecho de ese entonces. La representación como institución del derecho público tenía diversas manifestaciones, algunas de las cuales databan de la Edad Media. Por eso las diferencias surgieron en torno a si era posible una compatibilización de las nuevas necesidades políticas con el sistema jurídico vigente o si por el contrario, la constitución exigiría el diseno de instituciones que representaran una ruptura con el pasado y la tradición. Es así como el diputado Quintana propuso inmediatamente que cada casta americana fuese representada sólo por un miembro de su estamento y que se les permitiese votar pero no ser elegidos para ocupar cargos dentro del futuro poder legislativo ${ }^{80}$. Obviamente dicha propuesta encendió los ánimos. De la representación estamental se pasaba a una de carácter étnica y racial. En ese momento varios vaticinaron la pronta emancipación política americana producto de la discriminación de que los americanos eran objeto y de un sistema económico en el que unos reinos predominaban sobre otros y España sobre los reinos americanos en su conjunto ${ }^{81}$. Para el diputado José Miguel Guridi y Alcocer ${ }^{82}$ a solución era sin embargo fácil: libertad de trabajo, libertad de comercio e igualdad en el acceso a los cargos públicos: 'Los remedios a tal problema se reducen a la igualad de derechos en los frutos y en los destinos, en los frutos para que puedan sembrar y cultivar lo que es capaz el terreno y permutarlos o venderlos a quien necesite: igualdad en los puestos para que se premie a los que se lo

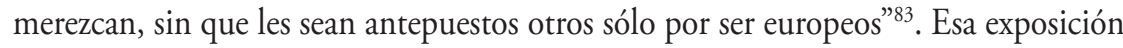
de corte liberal dieciochesco se vio complementada con la del diputado Felipe Aner ${ }^{84}$, quien sostuvo que todo se solucionaría con la igualdad de derechos y la igualdad en la representación en las Cortes ${ }^{85}$. Ambos diputados sintetizaron muy bien el deseo de los representantes americanos. Los peninsulares consideraron que las propuestas eran razonables pero no accedieron a ellas con la excusa del carácter extraordinario de esas Cortes y en que no se disponía de información fehaciente acerca de la población americana. Luego de ello se insistió en tratar a los americanos como súbditos, mas no como ciudadanos. Varios peninsulares propusieron una categoría de ciudadano que disociaba tal calidad de los derechos políticos que le son inherentes. Se planteó que los americanos no necesitaban derecho a voto sino un mejor reconocimiento de la libertad civil, la propiedad y la seguridad personal ${ }^{86}$.

\footnotetext{
Cortes Generales (1810 - 1813), op cit. p. 327

Cortes Generales (1810 - 1813), op cit. p. 328

Diputado propietario por la cuidad de Tlaxcala, México. Doctor en Cánones y Teología, se desempeńaba como párroco al momento de viajar a Cádiz. Se destacó por ser uno de los diputados liberales más avanzados de las Cortes.

${ }^{84}$ Diputado por Cataluńa, de profesión abogado, de pensamiento político conservador, aunque de posturas que oscilaron entre absolutistas y liberales.

85 Cortes Generales (1810 - 1813), op cit. p.329

86 Es obvio que en este punto había una manifiesta confusión conceptual en muchos de los que opinaron. El debate en las Cortes de Cádiz era muy abierto. Cualquiera podía opinar.
}

83 Ibid. 
A poco andar el debate decantó y se recurrió al argumento clásico del constitucionalismo dieciochesco para frenar los ímpetus de igualdad y contener los temores de los grupos dirigentes. Dicho argumento trataba al derecho a voto como un privilegio y un reconocimiento a la calidad humana, moral e intelectual de cierta persona. No todos tenían derecho a voto y eso era entendible pues todos debían cumplir con los requisitos que para ello establecía la ley. El derecho a voto es un reconocimiento a una serie de cualidades y por ello se aspira a que su acceso sea de carácter restringido. El derecho a voto es la culminación de un proceso de cultivo intelectual e independencia económica. Gracias a ese cultivo se podía participar en la cosa pública. De acuerdo a esa concepción la ciudadanía era una nueva forma de nobleza. Era un premio al mérito del que sólo se hacía merecedor el que supiese leer y escribir y pudiese sustentarse por sus propios medios. La doctrina constitucional de esa época consideraba que sólo era digno de participar en la conformación de la voluntad soberana y dirigir los asuntos y destinos de una sociedad aquel que podía sustentarse por sus propios medios.

Como en toda época, el privilegio ha sido un móvil de los seres humanos. Cada sociedad genera su propio sistema de privilegios ${ }^{87}$. Para el primer constitucionalismo la igualdad tenía un contrapeso en el voto, sinónimo de virtud ${ }^{88}$. Sin embargo, los constitucionalistas no habían previsto aún como se entendería ese privilegio en una sociedad multiétnica y con diferencias sociales y culturales tan marcadas como las del imperio hispano. Tal definición fue elaborada al calor de los debates. Los peninsulares explicaron su concepción en base al significado jurídico de los principios de igualdad, la fraternidad y la libertad, entroncándolos con las Siete Partidas y otros fueros medievales. Curiosamente en este punto los americanos mostraron argumentos mucho más contemporáneos que los peninsulares; aunque estos tuvieron un énfasis más político que jurídico. Fernández de Leiva fue en este punto el encargado de suplir ese déficit. Partió proclamando la necesidad de emancipar a la nación de la esclavitud, entendiendo por ella la amenaza que representaba Napoleón y los franceses y la ausencia de felicidad que han padecido muchos miembros de la nación hispana. Por ello no le cabía duda que se aceptaría la igualdad de representación en las Cortes para América y las Filipinas. Protestó sin embargo por las distintas maneras en que las Cortes procedieron a elegir a los representantes americanos. Estos eran inferiores en número y la inmensa mayoría de los diputados del nuevo continente no fue electa por los habitantes de sus unidades territoriales. Tal situación ya implicaba alguna carencia de legitimidad frente a los habitantes de sus comarcas. Planteaba que por si esto fuese poco, las Cortes le reconocieron derecho a participación sólo a algunas ciudades y cabildos, privando a amplias regiones de Indias de sus derechos políticos. Por último,

87 Recogemos esta cita de las conversaciones sostenidas con el filósofo y profesor de la Facultad de Derecho de la Universidad de Chile don Miguel Orellana Benado, quien sostiene que ese es el motor de los seres humanos para actuar. En esta cita a pie de página es lamentablemente imposible entrar a describir los fundamentos de la opinión del mentado académico; pero al que escribe estas líneas le parece que su descripción del actuar de los humanos en este punto es muy acertiva.

88 Una excelente explicación de este planteamiento, centrado en la Montesquieu, lo ofrece el libro Cuestiones Constitucionales, del jurista peruano Toribio Pacheco, escrito en Puno el ano 1854. Tuve acceso a él gracias a una copia digital que el profesor Carlos Ramos Núnez tuvo la gentileza de poner a disposición del que escribe. 
fijar arbitrariamente el número de diputados americanos en sólo 30 era desconocer el número y el aporte de esos súbditos a la Corona. En su opinión tal situación implicaba poner en tela de juicio todo el trabajo que significaba la elaboración de un nuevo pacto político. Alegó que al mismo tiempo, los peninsulares estaban sobrerrepresentados, pues había diputados que participaban de las cortes por elección popular y otros por representación corporativa, a la que tenían derecho algunas cortes y ciudades. Luego de ello expresó que el fundamento de la igualdad en la representación no era otro que el reconocimiento expreso de la igualdad y de la soberanía nacional contenido en el decreto del 15 de octubre. Manifestó que desde el momento en que se trataba de cimentar una monarquía constitucional con base en la nación lo determinante era que en ese Congreso Nacional se reuniese de la manera más representativa posible a todos los que componían la nación espanola. Tal debía ser el fundamento de los criterios de elección de representantes. El principio ordenador era que todas las partes de la monarquía pudiesen elegir a sus representantes en base a criterios iguales. El creía que el principal objeto del congreso era indagar la voluntad general de la nación y para ello era imprescindible evitar que una provincia tuviese un influjo mayor que otra en base a otros principios que fuesen la igualdad.

Fernández de Leiva comprendió que la mayor amenaza para un nuevo orden dentro de la Corona hispana era una defectuosa configuración de ese congreso. Le preocupaba que este careciese de toda la pluralidad existente en los territorios de la corona espańola y que algún sector de la sociedad quedase sin representación producto de las distorsiones propias de todo sistema electoral. Si tal situación acaecía se corría el peligro que unas provincias impusieran sus intereses a otras, atizando así los conflictos regionales ya existentes en Indias. El consideraba que el gran poder del Estado era el legislativo y por ello la igualdad de representación era la base de cualquier otro derecho. Hacer cualquier cosa en contrario significaba además desconocer los principios consagrados en el decreto del 15 de octubre.

La argumentación de Fernández de Leiva representó la superposición de la igualdad numérica por sobre los equilibrios geopolíticos. De acuerdo a su idea sobre qué debía ser una monarquía constitucional, esta necesitaba una base democrática. Dicha base era en ese caso la indagación de la voluntad de la nación. La nación a su vez estaba conformada por todos y ella como sujeto político debía ser preferida a los reinos o provincias.

Rebatió el argumento referido a la imperiosa necesidad de avanzar rápido en la redacción de una nueva constitución y postergar este tema, toda vez que había empantanado la gestión de las Cortes, señalando que se había formado ya una comisión encargada; pero que todo su trabajo sería infructuoso si los comisionados no estaban al tanto de que concepto de igualdad y representación tenían los diputados de la Corte. La igualdad era uno de los principios fundamentales de la nueva constitución y ella debía corresponderse con lo que por ese principio entendiesen los diputados. No habiendo un concepto claro de igualdad, era muy difícil avanzar en la redacción de un nuevo texto fundamental. No se podía colocar la carreta delante de los bueyes. 
Por último sobre el argumento que las Cortes tenían un carácter de extraordinario y por ello no se podían hacer cargo de tan delicado tema, con palabras propias de la terminología jurídica de su época manifestó que se estaba ante una asamblea constituyente, cuyas facultades no se podían ceñir a lo que tradicionalmente se había entendido por Cortes. Ellas no estaban sujetas a los príncipes sino a la nación y como tal su labor era buscar la felicidad de la Nación y "establecer un pacto social que, asegurando los derechos del Trono, precaviese los medios que conducían a los errores del despotismo".

Criticó de paso la estrategia política asumida por los peninsulares de reiterar por medio de circulares y declaraciones la necesidad de proteger a los aborígenes pues significaba desconocer el rol que jugaba el derecho indiano. Fernández de Leiva cerró el debate con la obligación de aceptar la igualdad de derechos de naturales y originarios de ambos hemisferios ${ }^{89}$.

Los argumentos de Fernández de Leiva vencieron pero no convencieron. Los peninsulares no renunciarían a la idea de una sociedad de castas. Era su baluarte frente a la amenaza de perder la preponderancia y la hegemonía política.

Los argumentos de Fernández de Leiva, definidos por el Conde de Toreno como brillantes en ciencia y resolución ${ }^{90}, \mathrm{v}$ cerraron una etapa de esta discusión. Después de ese discurso la manera de instalar el debate sería más sutil y susceptible de transacciones ideológicas entre las distintas posturas. Americanos y peninsulares requerirían de mayor fineza jurídica a la hora de redactar los artículos. Ello obligó a los diputados doceañistas a volver sobre la pregunta, en base a qué somos iguales o mejor dicho, sobre qué cualidades de los nacionales no se puede hacer diferencia. Este entramado de preguntas sería respondido poco después con ocasión de la regulación de la ciudadanía. En ese vínculo jurídico confluirían las ideas de igualdad, privilegio, representación y nación.

El trasfondo de esta discusión siempre fue el mismo: en primer lugar subyacía el temor de los peninsulares a quedar en minoría en las futuras Cortes y en el segundo se encontraba la configuración de un concepto e idea de nación que chocaba con el acervo jurídico existente. Al ser la nación la suma de todos los individuos, la participación de estos entraba a ser mucho más importante que la representación de los reinos en cuanto unidades políticas. Mucho más populosas eran las ciudades americanas que las peninsulares; por ende los peninsulares buscaron una nueva estrategia para mantener el statu quo: la asimilación. La idea fue que sólo el americano que respondiese al estereotipo de lo que debía ser un peninsular pudiese adquirir la ciudadanía. El grado de asimilación que los individuos alcanzasen en América determinaría si eran merecedores del privilegio de votar. Sólo tendrían derechos políticos aquellos que, por su similitud al peninsular, podían ser considerados como tales. En otras palabras, la categoría de americano o nativo de este lado del atlántico desaparecía. Dicho criterio implicaba una sutil forma de discriminación: te acepto en la medida en que eres similar a mí. Con esa argumentación la sociedad de castas seguía vigente. Así se mantendría el estatuto

89 Cortes Generales (1810 - 1813), p.384-387.

90 Conde de Toreno (I 872 ), op cit. p.308 
jurídico de incapaz relativo del indígena y el descendiente de africano seguía siendo sólo un objeto de protección. Ambos grupos mantenían su cultura y se mostraban reticentes a cualquier intento de transculturación. En el caso que el esclavo terminase sus días como liberto, sus hijos eran castigados por su origen. De este modo se reduciría la base de representación americana y se lograba garantizar la hegemonía peninsular. En otras palabras, el privilegio de votar se transformaba un premio para aquellos que se transculturaban de manera exitosa ${ }^{91}$.

Obviamente el debate derivó en una discusión acerca de qué se entiende por raza, cuáles eran las razas de los habitantes de América, qué características determinaban el estereotipo indígena y el africano y qué virtudes podían ellos detentar.

En esta discusión los diputados americanos carecieron de estrategia para manejar el debate y si bien la ignorancia de muchos de los diputados peninsulares acerca de la realidad social americana posibilitó hacer brillantes defensas, nunca pudieron torcer el debate a su favor.

Para fortuna de las posiciones sustentadas por los americanos, este debate se dio en fases, lo que dio tiempo para una mejor preparación y articulación de los argumentos. Gracias a ello, en la discusión definitiva, la que derivada del análisis en sala del proyecto de constitución, inclusive fue posible distinguir entre aquellos que querían una mayor participación de los americanos posturas moderadas y exaltadas.

Un rol curioso jugó en este punto el chileno Fernández de Leiva. En su calidad de miembro de la comisión de redacción de la constitución debió explicar los alcances del artículo 18 del proyecto. Este establecía que eran ciudadanos los espańoles que por ambas líneas fueran originarios de territorios pertenecientes a la Corona y que estuviesen avecindados en cualquier pueblo ${ }^{92}$. La idea fue excluir a todos aquellos que tuviesen alguna ascendencia africana, pero hubo opiniones disidentes como la de él. El consideraba que un ingenuo ${ }^{93}$ también merecía ser ciudadano si ejercía una industria útil y/o podía vivir del producto de su trabajo, es decir, si era virtuoso, y estaba avecindado ${ }^{94}$ en estos territorios ${ }^{95}$. Claramente propuso una norma de carácter

91 Esa virtud fue conceptualizada por Montesquie acorde con su sentido etimológico como valor, fuerza, poder, grandeza de alma, las que según el ya citado Pacheco el jurista francés las conceptulizó como amor a la patria y a la igualdad. En Pacheco (1854).

92 Cortes Generales $(1810$ - 1813), op cit. p.1753

93 Este concepto viene del derecho romano y se refiere al hombre nacido libre, es decir, aquel que no nació como esclavo. Era la oposición al liberto, es decir, aquel que siendo esclavo había sido manumitido.

94 Si bien la postura de Fernández es de avanzada si se la compara con la emanada de la comisión, importante es señalar que estuvo sujeta a críticas. Su postura exhibía una fuerte influencia indiana. La idea de vecino venía de las Partidas y según un sector de sus críticos, el criterio que debía adoptarse era el del nacimiento. Importante era haber nacido en alguno de los territorios que integraban la Corona El requisito de nacimiento no hacía discriminación en aras de los antepasados y para determinar si una persona reunía las cualidades para ser ciudadano lo importante era el sujeto acreedor de esa calidad; no sus antepasados. Los que argumentaron eso hicieron alusión al derecho romano y al griego, en cuanto al otorgamiento de la ciudanía en ambas culturas. Varios consideraban que el requisito de vecindad daba lugar a discriminaciones que, desde una perspectiva igualitaria, no eran aceptables y que en ese punto se debía superar a Las Partidas, texto que servía de apoyo a los que mantenían posturas esclavistas. Por lo demás se argumentó que si lo importante era reconocer la virtud, los orígenes importaban poco, pues la virtud era un conjunto de características personales que no tenían relación con los orígenes de cada uno.

95 Ibid. 
ecléctico que no despertase el miedo entre los españoles y que mejorase la posición de América ${ }^{96}$.

En este punto Fernández logró con su propuesta abrir un debate ${ }^{97}$, en el que varios diputados, apoyados en el modelo del ius latis minus y el ius latis maius, plantearon que el origen era irrelevante para la concesión de la ciudadanía y el vecindario no era admisible como requisito. En la práctica, acabar con el origen era una nueva manera de atacar el concepto de castas y otorgarle a los americanos un mayor protagonismo y participación. Mediante la exclusión de los no eran descendientes de españoles por vía materna y materna se le negaban los derechos políticos a parte importante de la población en Perú, México, Cuba, etc. Se argumentó que por esa vía se privaba a España de mano de obra calificada, se castigaba a personas por factores que no podían cambiar, como eran la familia y el origen. Además, se manifestó una clara postura de oposición hacia esos requisitos por considerarlos además clasistas. El diputado José Miguel Gordoa ${ }^{98}$ dijo: "aparecen gozando el dulce título de ciudadanos todos los de las clases precisamente consumidoras, mientras que las productoras, es decir, las más dignas o con más justicia, para obtener este título son despojadas de él"99.

Esta discusión se prolongó por varios días y el mismo Fernández de Leiva admitió, en sesión del día 6 de septiembre, que después de escuchar las impugnaciones a su proyecto y al de la comisión, cambió de parecer. Así terminó manifestando su disconformidad con lo que en definitiva sería el artículo 22 por establecer requisitos casi imposibles de cumplir para personas provenientes de una clase social que había sido humillada durante siglos. Propuso una política que resarciese a los actuales miembros de ese grupo por los perjuicios sufridos por sus antepasados. Fernández resumió su crítica al mentado artículo con la frase: "los dejaban reducidos a la nulidad"100. El reconoció poseer una interpretación restringida respecto al otorgamiento de los derechos políticos; pero consideraba que mayor peligro para un sistema político era que los individuos que ocupan las altas jerarquías y en los que recaer la responsabilidad de gobierno sean personas de poco carácter o de baja calidad moral. Era inadmisible restarle al sistema político la posibilidad de contar entre sus filas con gente valiosa mediante requisitos casi imposibles de cumplir producto de las privaciones a las que habían sido sometidos durante muchísimo tiempo. Planteó una suerte de discriminación positiva, que antes

96 Fernández de Leiva no fue el único que buscó en este punto una transacción que dejara relativamente satisfechos a ambos grupos. Es así como el diputado Terreno propuso se reconociese la calidad de ciudadanos a todos los anotados en los libros parroquiales; pero que no todos pudiesen ejercer los derechos que esta calidad implica. Para ello proponía que estuviesen habilitados para ejercer los derechos políticos todos los españoles y los que estuviesen anotados en los libros de las castas que hayan nacido libres e hijos de un matrimonio legítimo. CoRTES Generales (1810 - 1813), op cit. p. 1762.

97 Cortes Generales $(1810$ - 1813), op cit. pp.1762 y siguientes.

98 Diputado propietario por Zacatecas, doctor en Teología y Cánones en la Universidad de México. Llegó a ser vicepresidente de las Cortes.

99 Cortes Generales (1810 - 1813), op cit. p.1.766

100 Cortes Generales (1810 - 1813), op cit. p.1.786. 
que nada reconociese el esfuerzo personal y el ánimo de superación. Lo contrario era desconocer el valor que una sociedad debía entregarle al mérito y la virtud ${ }^{101}$.

Desgraciadamente en este punto pesó sobre los constituyentes americanos su corto número en comparación con los peninsulares. Les faltaron los votos. Sólo lograron que se concediese una norma especial para los descendientes de africanos, los que de ser virtuosos podrían obtener de las Cortes una carta de ciudadanía, siempre y cuando estuviesen casados con mujer ingenua, fuesen hijos legítimos de matrimonio entre ingenuos y estuviesen casados con ingenua. Se morigeraron las discriminaciones en razón del origen; pero no se reconoció el hecho que la virtud era una característica eminentemente personal ni se consiguió la derogación de la sociedad de castas ${ }^{102}$.

Esta discusión volvió a instalarse con ocasión de la discusión de los artículos $28^{103}$ y $29^{104}$ del proyecto. El primero establecía los criterios de representación territorial y el segundo regulaba de nueva manera la ciudadanía, esta vez mediante el criterio de qué se entendía por población. Este último era ntendido como lo que hoy es el pueblo, detentador de la soberanía popular. Nuevamente los diputados americanos resultaron perdedores. Fernández de Leiva, en su calidad de comisionado disidente, partió señalando que todos los diputados americanos, con excepción de uno, estaban en desacuerdo con el proyecto. Por el primero de los artículos Espańa y América tendrían igual número de representantes en las Cortes y por el segundo al establecer que por ambas líneas sean originarios espańoles quedaban sin derecho a participación los indios, los negros, los mulatos, los zambos y los mestizos. Fernández de Leiva dijo que estos dos artículos transformaban en letra muerta los principios de la Constitución. Los grupos excluidos también serían destinatarios de las leyes que las Cortes promulgasen en el futuro y por ello debían también ser representados y tener derecho a voto. De lo contrario, el nuevo sistema político carecería de legitimidad ${ }^{105}$.

El último aspecto de la regulación de la ciudadanía en el que Fernández de Leiva tuvo participación en el pleno tuvo relación con la virtud. Esta era el fundamento de la calidad de ciudadano y además fue el fundamento del artículo 25, que establecía los requisitos habilitantes para poder ejercer esos derechos. Fernández de Leiva sólo intervino señalando que no puede ser ciudadano el ignorante, y el presumía que el analfabeto lo era. Por ello era imprescindible que el requisito de saber leer y escribir fuese entendido no sólo como una condición exigible desde el año 1830, sino también como una de carácter resolutorio para todos aquellos hasta esa fecha ejerciesen el derecho a voto y sin embargo no hubieran aprendido a leer y escribir. Si en ese momento no lo sabían,

\footnotetext{
101 Cortes Generales (1810 - 1813), op cit. pp. 1785-1787

102 Artículo 22.

103 Dice el proyecto y en definitiva la carta fundamental: "La base para la representación nacional es la misma para ambos hemisferios."

104 Dijo el proyecto y luego el texto definitivo de la pepa: "Esta base es la población compuesta de los naturales de los dominios espańoles que por ambas líneas sean originarios de los dominios espańoles...”

105 Cortes Generales (1810 - 1813), op cit. p. 1.844.
} 
se les debía suspender la calidad de ciudadanos. Para él la instrucción y la educación de la masa debían ser una política de Estado ${ }^{106}$.

Otra manifestación de esa igualdad se dio con ocasión de las reformas administrativas tendientes a fortalecer el Estado. En este punto los diputados fueron en general bastante más prudentes a la hora de implementar políticas públicas. En esta materia realmente hubo una diferenciación permanente. Se partía de la base que había movimientos independentistas en América, por lo que la implementación de políticas necesarias para Espańa en América podía atizar el descontento en esta parte del globo y no corresponder a la realidad existente en estos reinos. Es así como Argüelles, con ocasión de la discusión de un impuesto especial a toda la plata labrada en poder de particulares o de la Iglesia señaló: "la desconfianza que por lo común tengo al hablar de las cosas de América crece todavía más cuando reconozco indispensable el conocimiento local para opinar en materias que no pueden resolverse con acierto sin tener aquel en suficiente grado" ${ }^{107}$.

En síntesis, se puede senalar que los americanos tuvieron en este punto una posición clara -aunque no exenta de matices- tendiente a obtener un estatuto que, si no les proporcionaba alguna ventaja, al menos no los dejara en la misma posición en la que estaban hasta entonces. La actuación de Fernández de Leiva fue muy acorde con el constitucionalismo dieciochesco, igualdad matizada con la virtud, entendida esta última como la capacidad del individuo para entrar a decidir cuestiones de Estado y participar de la formación de la voluntad nacional por medio del voto. En esta constelación entre el principio de la igualdad, el requisito de la virtud e instituciones como la representación y la ciudadanía optó por darle mayor importancia a la virtud que a la igualdad. Su idea central era que la cosa pública revestía tal relevancia que su manejo sólo podía estar en manos de los mejores: la virtud representaba en si una ruptura frente a la idea de un grupo o estamento per se habilitado para gobernar. Ahora se permitiría la participación acorde con los méritos personales. El postulado de Fernández de Leiva era que hombres virtuosos hay en todas las clases sociales y en todas las regiones. Reconocía que la virtud no podía asociarse con un estereotipo cultural, como era la persona blanca. Su idea de virtud se concretizaba a través de dos características personales: en poder sustentarse con su propio trabajo y en saber leer y escribir.

\section{La nación como fundamento del nuevo orden}

La máscara del rey para actuar como reformadores la usaron primero los liberales en España y luego un sector de los criollos en América. La ausencia del rey hacía que el poder volviese al pueblo, cuyos miembros eran los representantes de la nación. Ella era el fundamento y el destino de toda medida política. La felicidad de la Nación era

\footnotetext{
Cortes Generales (1810 - 1813), op cit. p. 1.817.

Cortes Generales (1810 - 1813), op cit. p. 845.
} 
también el fin último al que debía dirigirse toda norma constitucional. Tal posición filosófica, sin embargo no podía llevarse al extremo. Por ello era necesario jurar y declarar que se esperaba la vuelta de Fernando VII, al que se le atribuían toda clase de virtudes y capacidades propias de un ser infalible. Por algo era llamado "El deseado". Sin embargo, a medida que circulaban los rumores sobre un posible matrimonio entre Fernando VII y una princesa de la casa de Austria, o de su vuelta producto de una negociación con Napoleón, tendiente a restituirlo en el trono a cambio del avasallamiento del movimiento juntista, los diputados de Cortes se vieron obligados a discutir en qué condiciones aceptarían el retorno del monarca. La postura de Fernández de Leiva fue en ese aspecto radical: el partió señalando que quería a Fernando VII como Rey de España y no como hijo adoptivo de Bonaparte ${ }^{108}$. En caso de que algo así sucediese, la nación no podía reconocerlo como Rey ni aceptarlo. Para eso se basó en las nromas del pacto social que regían a la nación: "Si esto último sucediese, esta nación quedaría degradada y reducida a la clase de provincia... Ya sabemos lo que hace relación al interés de la Nación. Yo no repetiré principios; pero reconozco el interés que tiene la nación en no dejarse sujetar a los que no sean conformes al pacto social"109. Para justificar la juridicidad de su opinión recordó que en caso de locura la legislación hispana autorizaba nombrar tutores para el rey, y de verificarse alguno de esos rumores, estarían frente a un rey que sucumbió ante la presión psicológica de sus captores. De ser verídicas tales murmuraciones, se debería aplicar por analogía ese criterio. Para evitar tales posibilidades y una disolución de la nación espańola producto del descrédito que traería una lucha política y una guerra por nada; propuso que el Rey fuese reconocido sólo por las Cortes y sin ese reconocimiento no pudiese asumir su cargo ${ }^{110}$. En los hechos Fernández de Leiva supeditó la figura del monarca a la de la Nación. El poder residía en la última y el hecho que hubiese un rey que no cumpliese con los requisitos que ellos como representantes de la nación exigían los habilitaba para rechazarlo. En consecuencia, la figura del Monarca ya no era infalible y un monarca que no cumpliese con sus expectativas no sería aceptado ${ }^{111}$.

En la sesión siguiente, a raíz de esa y otros intervenciones se sometió a discusión un decreto que tenía por nulo un eventual matrimonio de Fernando VII en aras de su falta de voluntad. Es decir, las Cortes como representantes de la nación podían calificar la conducta del monarca. Fernández de Leiva no contradijo esta idea, no obstaante manifestar que consideraba tal acto jurídico como innecesario; pues la declaración de

\footnotetext{
Cortes Generales (1810 - 1813), op cit. p. 267.

Cortes Generales (1810 - 1813), op cit. 267.

Cortes Generales (1810 - 1813), op cit. p.268

En este punto las palabras de Fernández de Leiva tienen un carácter doblemente rupturista. Por una parte demuestran cómo se han desarrollado ciertas ideas, que pueden ser interpretadas como propias de la Ilustración, o propias de la escuela espańola del derecho natural o incluso como una interpretación moderada de algunos de los planteamientos de Juan de Mariana. Por otro lado, son rupturistas por el hecho de venir de un latinoamericano. Es inconcuso cuánto terreno había ganado la conciencia política en América. A comienzos del siglo XVIII, con ocasión de la guerra de la sucesión en Espańa, América contempló impertérrita los sucesos acaecidos en Espana y se genuflextó ante el que resultó vencedor en ese conflicto. Ahora toma parte, exije y pone condiciones.
} 
nulidad en este caso no tenía efecto jurídico alguno, validaba comidillos de pasillo sin tener certeza acerca de su veracidady daba una señal política de debilidad ${ }^{112}$.

Otro punto que muestra como el principal elemento del nuevo orden constitucional pasa a ser la nación se da a raíz de la advocación a la Santísima Trinidad. La tradición jurídica hispana acostumbraba a que en el encabezado de los textos jurídicos se hiciese una profesión de fe. No era normal que un texto jurídico importante sólo invocase a la divinidad. Tal ruptura con la tradición generó reparos, que fueron explicados de forma escueta por Fernández de Leiva. Se limitó a decir que la nación es la encargada de hacer la profesión de fe y no el texto en su encabezado ${ }^{113}$.

Otra de las discusiones en las que Fernández debió tomar parte fue en el artículo referido a los objetivos del gobierno. El proyecto establecía que la felicidad de la Nación era el objetivo del gobierno y que el fin de toda sociedad no era otro que la felicidad de los individuos que la componen ${ }^{114}$. Varios diputados entendieron el sentido de esa norma pero formularon que estaba mal redactada, por lo que propusieron que en lugar de ella se dijese "que la felicidad de la Nación consiste en el bienestar de sus individuos y que esta resulta de la conservación de sus derechos,.... Siendo este el objeto de la constitución y del Gobierno" 115 Fernández de Leiva dio su respaldo a la propuesta formulada; pero pidió que, en caso que esta no se aprobase, se conservase en el artículo la palabra gobierno; pues el pensaba que el objetivo de los tres poderes era la felicidad de la nación ${ }^{116}$.

Esta proposición fue aprobada, quedando el artículo redactado como que el fin del gobierno es la felicidad de la nación, que es el bienestar de los individuos que la componen. En este punto se recogió una técnica legislativa más bien antigua, que pretendía guiar la interpretación de las normas mediante ideas y conceptos extrajurídicos. Es un artículo y una discusión que refleja cuán hábiles fueron los juristas participantes de ese proceso para buscar una adecuada ecuación que equilibrase la tradición con las nuevas corrientes filosóficas y jurídicas.

En cuanto a los requisitos que debía cumplir el candidato a diputado de cortes, la comisión de Constitución estimó que era imprescindible que el candidato fuese nacido en la provincia que pretendía representar. Nación y sentimiento regional eran plenamente compatibles, pero se debía asegurar en aras de una óptima representación de la nación, que cada provincia fuese lo mejor representada posible. Correspondió a Fernández de Leiva, como miembro de la comisión redactora, exponer los fundamentos de ese requisito al plenario. Su argumentación fue escueta y clara. Para el todos los diputados debían cumplir dos funciones: "atender al interés público y general de la nación y; segunda, exponer los medios que puedan adoptarse para el bien de su

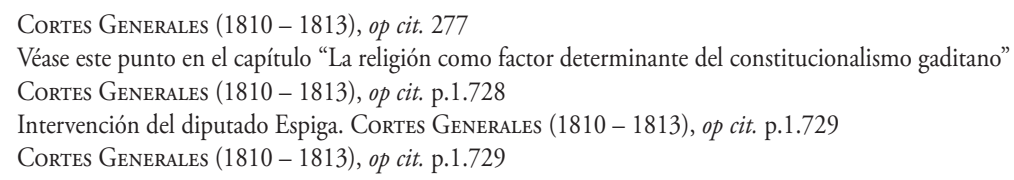


provincia"117. Para un adecuado cumplimiento de esas labores era menester, en opinión del investigado, haber nacido en el lugar a representar pues esto generaba un vínculo especial con el territorio que se traducía en un interés y un compromiso por su avance y prosperidad. En resumen, Fernández de Leiva partía del supuesto que el nacimiento en una zona era sinónimo de compromiso y afecto por ella.

La última argumentación que hizo Fernández de Leiva sobre este punto se dio a raíz de su voto disidente sobre la fecha de entrada en vigencia de la carta fundamental. El y los diputados Vicente Morales Duarez ${ }^{118}$, Andrés Jáuregui ${ }^{119}$ y Mariano Mendiola ${ }^{120}$ no aprobaron la norma que le otorgaba vigencia inmediata a la Constitución con un mero decreto de las Cortes generales y extraordinarias. Ellos creían que la nación necesitaba un tiempo para socializar esa carta. Ella debía necesariamente debía ser aprobada después de una convocatoria especial a Cortes, cuyo fin fuese la discusión y sanción de la nueva constitución. Los diputados citados reafirmaron que todo pacto relevante requiere un tiempo para su análisis y posterior aprobación, en aras de la mayor legitimidad posible. Ellos sostenían que la función de esas Cortes era reformar el ordenamiento jurídico y la mejor manera de lograr tal propósito era mediante la redacción de una nueva carta fundamental. Empero, atendida su relevancia, su promulgación no podía recaer en los mismos que la redactaron ${ }^{121}$. Así Fernández de Leiva expuso: "la constitución ha de ser un pacto al que se debe dar toda la estabilidad posible, conviene y es justo, que la nación, enterada de sus cláusulas, la acepte y jure libremente por medio de otra representación con poderes especiales" ${ }^{122}$. Fernández de Leiva creía que la única forma de evitar que la constitución sea conculcada, en vista de su difícil procedimiento de reforma, era otorgándole la máxima legitimidad posible mediante el proceso arriba seńalado. Una constitución muy rígida requería de un alto grado de aceptación para asegurar su vigencia. Él opinó que la manera en que se pretendía que entrara en vigencia suponía escaso consentimiento de la nación y ello amenazaba todo el trabajo hasta ese momento realizado. Según el investigado las constituciones podían entrar en vigencia mediante procesos en que hay poca participación, información y aceptación, pero ellas adolecen a la larga de problemas de legitimidad ${ }^{123}$. En ese punto manifestaron discrepar del Conde de Toreno. Este último compartía el diagnóstico y las aprehensiones de los cuatro disidentes; no obstante, creía que bastaba con el actuar de los diputados, lo que para Fernández de Leiva era muy peligroso. El chileno recordó que España estaba al borde de un cisma político. Siempre tuvo claro que la obra de

17 Cortes Generales (1810 - 1813), op cit. p.1.930

118 Diputado peruano. Doctor en Derecho Civil y Canónico. Profesor de Derecho en la Universidad de San Marcos, fundador del periódico el Mercurio Peruano, viajó a espana comisionado por el Cabildo de Lima y la Universidad homónima. De posturas más bien conservadoras, fue partidario de mantener la estructura social de castas en ese momento vigente.

119 Diputado por Cuba, para muchos uno de los lideres de los diputados americanos. Integró diversas comisiones y fue presidente de las Cortes en septiembre de 1812.

120 Diputado propietario por Querétero, México. Abogado de las Audiencias de Guadalajara.

121 Cortes Generales $(1810-1813)$, op cit. p. 2.478

122 Cortes Generales $(1810-1813)$, op cit. p.2.645

123 Ibid. 
los diputados doceanistas contaba con detractores dentro y fuera de Espańa y que no todos aceptarían los postulados liberales ni un nuevo pacto político ${ }^{124}$. Dicha postura fue apoyada en el foro por otros diputados americanos como Aner, Miguel Riesco ${ }^{125}$, Antonio Pérez ${ }^{126}$ y Martínez Robles ${ }^{127}$.

Fernández de Leiva vislumbró que uno de los desafíos de las constituciones escritas sería su adaptabilidad a la realidad social y política. El consideraba que la constitución debía ser flexible. En su opinión dicha flexibilidad exigía un procedimiento de reforma relativamente fácil de llevar a cabo.

\section{Principio de la División de los poderes del Estado como base del constitucionalismo gaditano}

En el constitucionalismo gaditano ese principio ocupó un lugar tan importante como en los otros modelos constitucionales entonces conocidos. Se creía que la fuente de toda arbitrariedad estaba en la reunión de muchas facultades en una sola persona, por lo que mientras más dividido entre distintos organismos estuviese éste, más libertad tendrían las personas y menos abusos serían posibles. Se pensaba también que la situación que en ese momento aquejaba a Espańa se debía, antes que nada, a que todo el poder estaba concentrado en la persona del monarca. La debilidad política de Espana estaba dada por el excesivo poder del Rey. División del poder significaba fortaleza institucional y término del despotismo. Napoleón había doblegado a Espana mediante el aniquilamiento de la figura del rey ${ }^{128}$. La idea de libertad que en ese momento existía era de carácter meramente negativo. Se buscaba una abstención del Estado al momento de ejercer poder. La constitución política debía ser una limitación de los poderes estatales; una limitación de su esfera de acción. Los derechos fundamentales jugaron un rol en esa carta fundamental; pero en ningún caso ese rol fue preponderante. De hecho la Constitución de Cádiz contiene declaraciones de las que se pueden deducir ciertos derechos básicos; pero en ningún caso un catálogo de estos. Esta idea queda muy bien ilustrada con las palabras del diputado José Espiga ${ }^{129}$ : "la Constitución no es más que la forma de gobierno con la que se han de ejecutar las leyes que han de formarse: cuando habló de legislación no hablo de constitución, sino sólo de la legislación que ha de juzgar los derechos de los ciudadanos entre si"130.

Diseñar una nueva institucionalidad siguiendo este principio no fue fácil, dado que al mismo tiempo se debía resguardar un razonable grado de efectividad en el desempe-

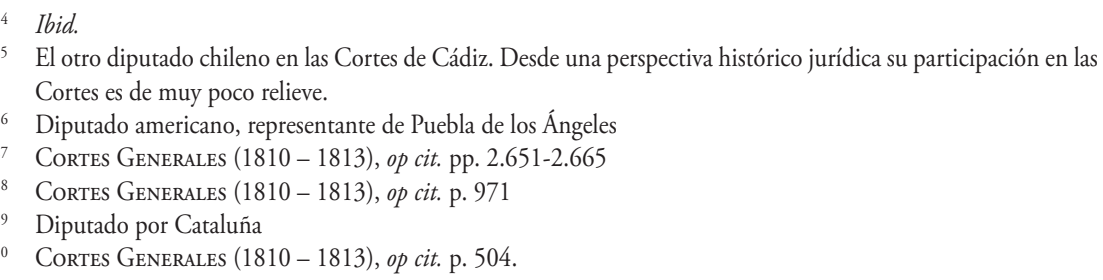


ño de las funciones. Situaciones que dan cuenta de lo complejo que fue delimitar la esfera de atribuciones de cada uno de esos organismos hay muchas y en varias de ellas Fernández de Leiva intentó orientar el debate. La primera de la que hay noticia en las actas se dio a raíz de la posibilidad de contratar los servicios de abastecimiento y víveres de una empresa inglesa. Había aprensiones de distinta índole entre los diputados. Fernández fue uno de los que autorizó, pues en su concepto el ministro que había solicitado la opinión de las cortes estaba tratando de resguardar su responsabilidad y asegurarse que su acto fuese conforme al principio de juridicidad. Por ello Fernández pidió que en el futuro se liberase al ministro de cargos por este acto ${ }^{131}$. Aunque no lo señala directamente, el pensaba que el rol del ministro era político, no administrativo.

También dio mucho trabajo compatibilizar ese principio con la adecuada representación de las cámaras. -poder legislativo- en la designación de funcionarios de responsabilidad en la Administración del Estado. Las cámaras representaban la soberanía nacional, por lo que debían conocer quiénes serían los responsables de la administración del Estado. Fernández de Leiva fue en este punto más pragmático y realista. Señalaba compartir estos argumentos y el derecho de las cámaras legislativas a intervenir en la designación de estos cargos, pero consideraba que la representación no podía ser obstáculo para la eficiencia y tampoco dar pie a que el ejecutivo se excusase del cumplimiento de sus funciones producto de diferencias políticas. El creía que las cámaras debían participar en la designación pero eso no podía significar el incumplimiento o el entorpecimiento las funciones administrativas y de gobierno ${ }^{132}$.

También trató Fernández de Leiva de ordenar los debates en base a este principio. Un caso se dio a raíz de determinar si el otorgamiento de una pensión era resorte de las Cortes o no, pues según la normativa que estas se habían dado, todos los ingresos del Estado debían gastarse de acuerdo a las normas que fijase el legislativo; pero había pensiones que eran responsabilidad exclusiva del ejecutivo. Antes de resolver el caso concreto el manifestó que era imprescindible determinar con mayor precisión cuál era el organismo responsable decidir aquellos gastos ${ }^{133}$.

Fernández de Leiva también se guió por ese principio en los debates acerca de la institucionalidad indiana. Como ya vimos más arriba, ese fue uno de sus motivos para solicitar la derogación de las normas que establecían las subdelegaciones; pero más importante que esa fue su intervención con ocasión del establecimiento de las secretarías de Indias. El proyecto de Constitución ordenaba en su artículo 222 la fundación de las Secretarías o Ministerios, siendo estas seis para Europa y dos para América. Tales eran la de Despacho de Estado; Despacho de la Gobernación del Reino ${ }^{134}$; Despacho de Gracia y Justicia; Despacho de Hacienda, Despacho de Guerra y Despacho de Marina. Las Secretarías para América eran denominadas Secretarías de Despacho

\footnotetext{
Cortes Generales (1810 - 1813), op cit. p. 125.

Cortes Generales $(1810-1813)$, op cit. p. 216.

Cortes Generales (1810 - 1813), op cit. 227-228

134 Esta secretaría, en opinión del diputado Borrull, era una copia de la que en Francia era conocida como Ministerio del Interior.
} 
universal de Ultramar. Una era para los asuntos de la América Septentrional y otra; para los de América Meridional. La idea de la comisión fue sentar las bases de una reforma administrativa en el Estado. El objetivo era que se encargasen de manera independiente y responsable de las diferentes funciones que el Estado debía cumplir en materia administrativa. Por ello los representantes de la comisión de Constitución no aceptaron como objeción el hecho que esto implicaría un aumento de los gastos en un momento de guerra; pues la guerra pasaría y la idea era que la reforma a la organización del Estado se perpetuase ${ }^{135}$. El fundamento de esta reforma fue imbuir a la administración del Estado de los principios de la ilustración. Había que modernizar la administración del Estado a fin que esta pudiese remover todos los obstáculos que impedían el progreso de los reinos de la Corona. Había que especializar en áreas a los funcionarios y a los ministros. Se buscaba que "la administración de justicia y la administración económicopolítica y gubernativa del reino anden enteramente separadas"136.

El relator del proyecto fue el diputado Terreno quien hizo presente que el diputado Fernández de Leiva había solicitado que cada Secretaría se votase de manera separada, pues era de la opinión que no se debían mezclar la naturaleza administrativa de las europeas con las americanas ${ }^{137}$. Tal proposición fue aceptada por lo que el chileno pudo exponer sus reparos ante un artículo del proyecto de constitución que no le satisfacía.

Fernández de Leiva argumentó que estaba fuera de discusión la necesidad de dividir las tareas administrativas de las gubernamentales. Tampoco era discutible que la creación de órganos especiales para América fuera una necesidad; pues ante la diversidad de tareas administrativas que debían cumplir los ministros, las exigencias del monarca y el la falta de especialización en ellas siempre América terminaba siendo postergada. Desde ese punto de vista valoraba la iniciativa; pero creía que la institucionalidad propuesta sólo agravaba los problemas pues concentraba un sin fin de funciones en una sola persona. Ello iba contra la idea de una especialización del trabajo gubernamental y daba un amplio margen a la arbitrariedad y el despotismo. Agregó "que podrá recaer una confianza tan vasta en un hombre de probidad a toda prueba; pero jamás ha sido, ni puede ser, el objeto del legislador fundar exclusivamente la utilidad de un establecimiento en la elección de las personas, sino en la mejor organización"138. Por esa razón y en base a la distancia y los costos que tenía elevar una queja ante la Corona, es que se opuso a dos secretarías de carácter universal. En su lugar propuso dividir el despacho de ultramar en tres categorías: una de Gobernación, Gracia y Justicia, otra de Hacienda y otra de Guerra y Marina ${ }^{139}$. Dicha proposición tardó meses en ser discutida y se agregó a otras ${ }^{140}$. En definitiva, las ideas de Fernández de Leiva fueron escuchadas y valoradas pero no lograron plasmarse en el texto definitivo.

135 Cortes Generales (1810 - 1813), op cit. 2.129. Intervención del diputado Aner.

136 Palabras del diputado por Valladolid, Espana, Evaristo Pérez de Castro.

137 Cortes Generales $(1810-1813)$, op cit. p. 2.128.

138 Cortes Generales $(1810-1813)$, op cit.p. 2.130

139 Ibid.

140 Cortes Generales (1810 - 1813), op cit. pp. 2.424-2.442. 
Volvió a demostrar gran criterio jurídico en la discusión del reglamento de regentes. Acá precisó que la ratificación de un tratado internacional por parte de las Cortes era un acto meramente formal. Ellas no podían entrar a revisar lo negociado por el ejecutivo. Sólo el ejecutivo podía llevar la responsabilidad de las relaciones exteriores. Él era el representante del Estado en el derecho internacional. Él manifestaba que cualquier confusión entre las funciones del ejecutivo y el legislativo significaría anarquía. Por esa misma razón se mostraba contrario a cualquier delegación de poderes por parte del Congreso. La facultad legislativa no era delegable en el ejecutivo en ningún caso. Eso sería volver al despotismo ${ }^{141}$.

Otra de las discusiones en que Fernández de Leiva exhibió su criterio fue dada por el nuevo sistema de gobierno de las provincias. El sostuvo en la comisión redactora de la Constitución que el gobierno de cada provincia debía recaer en un representante nombrado por el Rey, que gobernase junto a dos representantes de esa diputación. El creía que para combatir el despotismo se necesitaba contrapesar el poder unipersonal de los representantes del rey. Para la consecución de tal objetivo siempre era útil tener la colaboración y confianza de personas que cuenten con el respaldo y la popularidad de la provincia a gobernar. Además de constituir un contrapeso ante la concentración de poder, una autoridad colegiada era la mejor garantía de sujeción a la ley. Para los gobernados siempre era muy gravoso recurrir de queja a las instancias superiores de gobierno, sobre todo cuando se provenía de lugares relativamente aislados o de difícil acceso. En esos casos, mejor que hacer uso de los siempre honerosos medios formales que el sistema jurídico otorgaba, era contar con personas en el gobierno que pudiesen evitar la comisión de actos despóticos y garantizar el respeto por los gobernados. De esa manera se respetaría en parte la tradición de gobierno colectiva vigente en muchos de los territorios de la Corona. El sostuvo que esa idea en ningún paso ponía en tela de juicio a la monarquía, pues el rey seguía siendo Jefe de Estado. Por el contrario, el opinaba que su propuesta engrandecía la figura del monarca, al evitar que algunos en su nombre cometiesen tropelías y adoptasen medidas de gobierno poco prudentes. Esa propuesta fue acusada de consagración encubierta del federalismo, lo que él negó nadie había objetado hasta ese momento la figura del rey ${ }^{142}$.

Paralelamente, para asegurar un buen gobierno en cada provincia, se contempló la institución de la diputación, que de acuerdo al proyecto era un consejo integrado por el representante del Rey, el intendente y siete individuos, cuya función era promover su desarrollo y la prosperidad. En este punto surgieron en la sesión plenaria dudas de muy diversa índole, que el medio hermano de Manuel Rodríguez debió contestar. Aclaró desde un principio que la idea no era fijar en la constitución el número de distritos. Esa era materia de ley y siempre revisable. El criterio que en ese punto importó a la comisión era un gobierno eficaz. Sin embargo, para el diseño provisorio se partió de los distritos en ese momento existentes y en cada capital de distrito debía haber una

141 Cortes Generales $(1810-1813)$, op cit. p. 2.531.

142 Cortes Generales (1810 - 1813), op cit. pp. 2.606-2607. Claro queda del tenor de la discusión transcrita en las actas que no existía claridad acerca del concepto de federalismo. 
diputación. El reivindicó el derecho de las corporaciones a nombrar representantes en esas diputaciones emulando el florecimiento de la Minería y el Comercio, que cuentan con una institucionalidad de carácter corporativo ${ }^{143}$.

Importa destacar que Fernández de Leiva pensó en todo momento en una institucionalidad estatal de carácter colegiado y que reivindicó que las provincias recibiesen el mismo trato. En este sentido su actitud trae a la memoria uno de los grandes anhelos de los criollos chilenos, como era emanciparse de la tutela del Virrey del Perú.

Tampoco deja de ser relevante que buscase compatibilizar efectividad con legitimidad.

\section{Derecho uniforme, unificador y estatal}

Uno de los fenómenos que se desarrolla a la par con el constitucionalismo y la codificación en Europa es la uniformización y unificación del Derecho. Prácticamente todos los países de la Europa continental tenían distintos sistemas jurídicos vigentes en su territorio al mismo tiempo ${ }^{144}$. Cada persona tenía un conjunto de derechos aplicables propios y personalísimos, en razón de su lugar de nacimiento, religión, ciudad en la que trabajaba, estamento, oficio, etc. Esos estatutos iban acompañados de un sinfín de tribunales especiales y organismos de vigencia local. Dichos derechos significaban una seria restricción a la libertad personal y un desconocimiento de la igualdad, acorde con los parámetros ilustrados. Por otro lado, si bien todas las monarquías europeas conservaron sus facultades jurisdiccionales como tribunal de última instancia, acorde con las ideas vigentes en 1810 la jurisdicción era una emanación de la soberanía, y al residir esta en la Nación pasaba a ser tarea del Estado fundar una nueva institucionalidad judicial que detentase y ejerciese esta atribución sólo en su nombre. La explicación de este fenómeno se encuentra en el derecho medieval, en el feudalismo y la división de funciones entre el rey, el emperador y la Iglesia.

Este fenómeno se retroalimentaba con un fuerte sentido autonomista de las comunidades locales y su sentido de autogobierno. En la monarquía absoluta hispana el rey estaba obligado a respetar todos los derechos propios de cada comunidad a fin de ser aceptado por ellas. La identificación con los llamados derechos propios de cada región constituía parte de la identidad cultural en casi toda la Europa occidental y central. Así como cada región tenía su propio dialecto, cada una tenía su o sus propios derechos.

Esta situación tuvo también lugar en América, aunque por otros cauces. Gran parte de los conquistadores y posteriores emigrantes hispanos que llegaron a América venían de comunidades rurales y apartadas en las que el derecho común o romano-canónico

143 Cortes Generales (1810 - 1813), op cit. pp. 2.615-2.616.

144 Sólo a modo de ejemplo el sur de Francia se guiaba por el derecho romano y el norte por el germánico. En la actual Alemania este fenómeno fue llamado Rechtszerspliterung. Llegó a haber, en el siglo XVIII, más de 300 ordenamientos jurídicos vigentes en los territorios que hoy conforman ese país. 
no había llegado. Por ello desde un principio las ciudades americanas tuvieron una pluralidad de derechos y jurisdicciones. El derecho indiano como derecho de corte estatal y europeo destinado a regir en Indias, un estatuto indígena propio y además un derecho castellano vigente sobre todo en asuntos de derecho privado. Además con el paso del tiempo la Corona y las autoridades locales fueron dando a las diversas regiones una legislación especial, de aplicación territorial restringida tendiente a solucionar y regular las situaciones propias de la vida local. Los conquistadores, aparte de ello, desde un principio hicieron valer su sentido de autonomía y autogobierno, cuya máxima expresión administrativa fue el cabildo y la institucionalidad nacida a su alero. Su expresión jurisdiccional se dio, como ya se mencionó, a través de las constantes reclamaciones de suspensión de la normativa vigente por considerar que atentaba contra sus derechos adquiridos y/o conferidos por el Monarca o no ajustarse a la realidad ${ }^{145}$. Por esa razón la ley como fuente de derecho tenía muy poca fuerza normativa. De ahí la explicación del aforismo: "se acata pero no se cumple".

En consecuencia, cualquier política tendiente a la igualdad debía poner atajo a este fenómeno. Serán las constituciones las encargadas de iniciar esta discusión. La formulación de un nuevo pacto político implicaba necesariamente revisar este tipo de relaciones. Acorde con la nueva concepción de jurisdicción, la justicia y la ley debían ser una para todos los habitantes de los reinos que integraban la Corona, sin que la riqueza, la nobleza, la milicia, los estudios eximiesen a nadie de la potestad de los tribunales ${ }^{146}$. Además, el constitucionalismo. -al concebir como espacio público el Estado- procuraba a su expansión, por medio de más y mejor burocracia, nuevos organismos y más y nuevas atribuciones y funciones a cumplir por los ya existentes. Todos esos cambios estaban impregnados por la idea de una ley igual para todos. Todos se regirían por las mismas normas y en caso de haber diferencias o ser éstas consagradas por el derecho, la fundamentación de estas diferencias debería buscarse en argumentos distintos a los de una mera explicación histórica. En este aspecto, el constitucionalismo significó una disminución de las atribuciones y campo de acción de las comunidades locales, de la Iglesia, de los terratenientes y, en consecuencia, la emancipación legal de los vasallos.

En la realización de este objetivo el trabajo de las Cortes se dio más a nivel legal que constitucional. En este sentido el objetivo primordial e impostergable fue primero acabar con los seńoríos y luego que las magistraturas dejasen de aplicar los fueros. En el ámbito constitucional las discusiones que este proceso generó fueron más bien accidentales. A Fernández de Leiva le tocó en ellas un rol activo.

En la comisión se propuso que todo aquel señorío jurisdiccional existente en los territorios de la Corona fuese incorporado inmediatamente a la nación. Luego la comisión planteó que el aparato estatal debía contratar a los funcionarios públicos y

\footnotetext{
145 Es por esta razón que el derecho indiano concedió a las autoridades locales márgenes de libertad para administrar y gobernar los territorios relativamente amplios. Un buen enfoque para este tema está dado por el professor URQUiJo (2008), pp. 435-447.

146 LeVene (i956), p.106.
} 
judiciales necesarios para garantizar la administración de justicia. Asimismo los que actualmente desempañaban esos cargos deberían permanecer en ejercicio, siendo sus sueldos pagados por esos mismos pueblos o a prorrata entre los vecinos de cada señorío y, en caso de existir paralelamente funcionarios de señorío y reales, los primeros cesarían inmediatamente en sus funciones. Además propuso que el consejo de regencia fuese responsable de dictar inmediatamente una nueva regulación para los funcionarios judiciales y un nuevo sistema nacional de administración de justicia, que no dejase pueblo sin un juez competente. El mismo decreto abolía toda relación de vasallaje y/o feudalismo. Los que poseían señoríos sobre inmuebles desde ahora los verían incorporado a su patrimonio; pero estos perdían el carácter de institución de derecho público, despojándoselos así de sus facultades jurisdiccionales. Asimismo, se dejaban sin efecto todos los contratos de mera tenencia sobre inmuebles, en caso que permitiesen relaciones de vasallaje, y todo derecho de caza, pesca hornos, molinos, aprovechamiento de aguas y montes que coartase la libertad del usufructuante y reconociese a cambio derechos de carácter feudal. Los titulares de los señoríos recibirían por estas medidas una indemnización ${ }^{147}$.

En la discusión del texto constitucional esta tendencia volvió a provocar debate. En esta ocasión no fue la regulación de los señoríos sino la cláusula que establecía que territorios componían la Corona. Acá los constituyentes se guiaron por la enumeración de las grandes unidades administrativas, los reinos, tanto en América como en Espańa. En ese último territorio era algo delicado entrar a enumerar pues había muchas regiones que sin ser propiamente reinos gozaban de estatutos, organización política y una historia que les daba un fuerte sentido de identidad, pertenencia y afán de autonomía. Apenas leído en el plenario ese artículo se generó una discusión.

La omisión de ciertos territorios o la asimilación del orden de enumeración con una suerte de prelación entre las prioridades que tendría la Corona generaron una serie de dudas difíciles de explicar para los miembros de la comisión redactora. La discusión partió con la intervención del diputado Roa, quien manifestó su molestia por la omisión del señorío de Molina en el texto constitucional. Fundamentó la calidad de unidad territorial independiente de ese señorío en base a su permanente enumeración e identificación en las cédulas y pragmáticas, en una historia de más de seiscientos anos y en haber sido su reconquistador un soberano, que no tenía relación de dependencia ni vasallaje ni con Castilla ni con Aragón. Por eso Molina siempre fue considerado un reino. El diputado intentó probar ello en base a la historia del señorío, quienes fueron sus detentadores y la historia familiar de cada uno de ellos ${ }^{148}$. El consideraba que esa enumeración carecía de criterio. La comisión la habría redactado a su entero amaño ${ }^{149}$ .Argüelles respondió afirmando que había errores, pero que muchos de ellos se debieron a la inexactitud de la información sobre los límites de cada provincia, especialmente

147 LeVene (1956), op. cit. p.1.562

148 De acuerdo a la idea que aún había en la baja Edada Media en algunas regiones de España los reinos pertenecían al monarca, y como tal a su muerte corrían la misma suerte que el resto de su patrimonio.

149 Cortes Generales (1810 - 1813), pp.1742-1743. 
en América. Pero en definitiva el no tenía problema en hacer ese agregado. Luego el diputado Francisco Javier Borrull ${ }^{150}$ señaló que no debía olvidarse que había una serie de territorios nombrados en las cédulas y pragmáticas que no correspondían a reinos y que la clasificación administrativa de los territorios de la Corona no era lógica; pero ello no autorizaba agregar al señorío de Molina. Por esa razón se agregaba en seguida un artículo que contenía la obligación del Estado de diseñar una nueva división del territorio. Fernández de Leiva optó por poner paños fríos y concentrar la atención en este segundo artículo. No debe olvidarse que entre los diputados no todos eran liberales. Los había realistas y opuestos a toda reforma. Además, desconocer la relevancia de la identidad y los sentimientos regionales en un territorio que alberga poblaciones que inclusive hablaban distintos idiomas era jugar con fuego. Optó por evitar que en base al sentimiento regional se pusiese en tela de juicio la constitución o se la presentase como un texto que coartaría la libertad. Por ello solicitó agregar en ese artículo a Molina, pero no especificando que era un seńorío y justificando la necesidad de una nueva organización a fin de racionalizar y mejorar la administración de justicia y una mejor distribución de los recursos económicos.

Ese artículo también generó reparos, luego de agregar en el texto a Molina, por la omisión de Ceuta. Para dar tranquilidad a los diputados acerca del África se agregaron las palabras "las islas Canarias y las demás posesiones en África". Pero luego de ello vino la petición de una mención expresa para Yucatán, pues era un territorio grande, populoso y administrativamente independiente de Nueva Espańa. Además su gobierno espiritual no tenía relación directa con México. Fernández de Leiva estuvo dispuesto a apoyar la petición yucateca, no así la de Ceuta pues lo consideraba administrativamente dependiente de Sevilla ${ }^{151}$.

Esta discusión puso de manifiesto que uno de los desafíos del Estado Constitucional lo representaban los estatutos e identidades regionales. La pregunta de fondo acá era cómo se compatibilizaría esa necesidad de diferenciación con los principios de igualdad que orientaban al constitucionalismo. Ese artículo se usó como excusa para agregar entre las obligaciones del Estado un mejor diseño administrativo y una nueva división territorial. Acá hay una fuerte señal política de lo que deberá hacer el Estado con sus territorios. Reorganizarlos le permitía tomar una serie de atribuciones sobre ellos y paulatinamente, acabar con las manifestaciones administrativas y jurídicas de ese regionalismo, abriendo las puertas a una mayor centralización política y a una concentración de poder en el aparato estatal.

El artículo del proyecto constitucional que reconoce este fenómeno es el 257, que establece que los códigos civil, criminal y de comercio son los mismos para toda la monarquía, sin perjuicio de variaciones que las circunstancias pudiesen permitir ${ }^{152}$. Fernández explicó el alcance de esta norma. El valor fundamental que ahí primó era la

\footnotetext{
150 Diputado por Valencia, doctor en Derecho y profesor de derecho civil en la Universidad de Valencia, uno de los miembros de esa asamblea de mayor edad. Defensor de posiciones absolutistas

151 Cortes Generales $(1810$ - 1813), op. cit. p. 1749

152 Cortes Generales $(1810$ - 1813), op. cit. pp. 2.305-2.306.
} 
igualdad de todos los habitantes de la Corona ante la ley. Todos debían regirse por las mismas leyes. Los estatutos especiales sólo serían admisibles cuando las circunstancias lo justificasen. Su otorgamiento desde ahora sería atribución del Estado. Las comunidades locales perdían con ello la posibilidad de darse a sí mismas un derecho propio, ajeno a las competencias de la Corona. Ellas desde ahora a lo más podrían hacer presente situaciones que las harían merecedoras de un estatuto especial por medio del derecho de petición.

La actuación de Fernández de Leiva tuvo mucho de sentido de responsabilidad política y resguardo del proyecto constitucional. Por eso se optó por respetar los sentimientos autonómicos y alterar el proyecto de texto, a cambio que se reconociese que el Estado debía aumentar su esfera de atribuciones e implementar un nuevo ordenamiento jurídico sobre la base de una óptima utilización de los recursos, para cumplir de mejor manera las funciones que la sociedad y la nueva filosofía le encargaban. A diferencia de otros temas en los que Fernández de Leiva tomó parte activa, es necesario precisar que de las actas citadas no queda del todo claro si, más allá de los fines buscados, el chileno estaba del todo conciente de las consecuencias que en este aspecto el constitucionalismo traía.

\section{Administración de Justicia}

La administración de justicia fue otra de las prioridades de los constituyentes gaditanos. Todos querían una rápida y eficiente administración de justicia ${ }^{153}$, procesos más cortos y una pena que sirviese de rehabilitación al reo. Para ello se requería una reforma procesal.

En esta área el trabajo de las Cortes se materializó a través de la comisión de justicia, que en los hechos tuvo la doble función de legisladora, mediante dictámenes de carácter general, y también jurisdiccional, al actuar como tribunal, recibiendo reclamaciones de sujetos particulares, que protestaban por medidas del poder judicial que consideraban discriminatorias o contra ley. En los hechos intentó en varios casos revocar medidas por considerar que no se ajustaban a la nueva legalidad. Además de eso, esa comisión fue responsable de las visitas semanales a las cárceles, a fin de controlar el trabajo de los tribunales y la correcta aplicación de la nueva normativa. Así la comisión se formó una acabada opinión de la situación procesal vigente en ese momento.

La comisión llegó a la conclusión que las principales causas del retardo en la administración de justicia eran un deficiente conocimiento de jueces y funcionarios judiciales del derecho vigente y la manera en que las leyes estaban redactadas. Consideraba que los textos eran oscuros y admitían varias interpretaciones, por lo que no había uniformidad al momento de interpretar las normas de carácter procesal. En consecuencia las personas no tenían certeza acerca de sus derechos ni facultades. Tampoco

153 Cortes Generales (1810 - 1813), op. cit p. 818 
la libertad individual era entendida como un derecho fundamental. Por ello planteaba que era urgente dictar una ley que consagrase la libertad individual como un derecho y reconociese la detención y privación de libertad como una situación excepcional que sólo se podía verificar en los supuestos contemplados por la ley. Planteaba la urgencia de una reforma procesal penal que determinase claramente las etapas y actos jurídicos procesales esenciales y que reglamentase las visitas a las cárceles, pues estas se practicaban de manera muy distinta en cada reino de la península. Asimismo, la comisión exacerbó su desconfianza hacia la judicatura, por lo que proponían sanciones disciplinarias draconianas contra los jueces que no fallasen conforme a la ley vigente.

En este sentido, a fin de un mejor control sobre los tribunales, se propone que todos los plazos del proceso penal tengan el carácter de fatales, para así poder sancionar a todos aquellos jueces que no los observan.

También dicho informe constató que sobre un significativo número de presos no había información ni en los tribunales ni en las cárceles acerca de la duración de su condena ni del delito por el cual se les encarceló. Por esa razón, la comisión propuso a las Cortes que se pusiese en libertad inmediata a todos aquellos presos sobre los cuales no había información en tribunales ni en las cárceles; y que las Cortes designasen una comisión permanente de visitas.

Además se proponía un reglamento especial para los encargados de cárceles, que estableciese que a nadie se le podía encerrar en ese recinto sin documento certificado del tribunal competente ${ }^{154}$.

Ciertamente esa tarea implicaba una sistematización distinta de la legislación penal hasta entonces vigente. Por ello algunos diputados propusieron como solución un plazo perentorio de un ańo y medio para fallar las causas, agregar obligaciones ministeriales al juez, dividir el proceso en una etapa sumaria y otra acusatoria y establecer un término probatorio especial ${ }^{155}$. Fernández de Leiva valoró mucho esta propuesta pero propuso una idea distinta: la recepción y adaptación de alguno de los códigos penales en ese momento vigentes en el derecho comparado. Era de la opinión que cualquier código penal vigente en Europa sería más sencillo y estaría mejor sistematizado que las recopilaciones de leyes hispanas. Además probablemente tendría un lenguaje más simple y entendible y estaría informado por los principios de la ilustración ${ }^{156}$. Creía que el proceso penal debía ceñirse al principio de la inmediación del juez en la etapa de discusión y en la probatoria y que siguiendo el principio de la inmediación se debería exigir la asistencia del juez a los actos jurídicos procesales. De esa manera sería mucho más fácil hacer efectiva la responsabilidad ministerial del juez ${ }^{157}$.

154 Cortes Generales $(1810$ - 1813), op. cit. pp. 1.029 y siguientes.

155 Cortes Generales $(1810$ - 1813), op. cit. p. 1.092

156 Pese a existir esfuerzos permanentes de la Corona por sistematizar las legislación vigente, España inició tarde su proceso de codificación. De hecho, el primer texto jurídico de importancia del siglo XIX fue la Novísima Recopilación, a la que se le criticó su extemporaneidad, pues implicaba el empleo de una técnica obsoleta en el momento en que Francia y Austria ya habían dictado sus primeros códigos.

157 Cortes Generales (1810 - 1813), op. cit. p. 1.094 
La comisión de justicia jamás diferenció entre investigar y juzgar un delito. Ambas funciones debían ser realizadas por el mismo magistrado ${ }^{158}$.

Un aspecto importante que debieron enfrentar las Comisiones de Constitución y Justicia fue la creación de un poder judicial. Para ello recurrieron al modelo jerárquico piramidal. Tal modelo implica un tribunal superior. Esa institución fue vista con suspicacia por no pocos diputados. A modo de ejemplo, el Conde de Toreno se mostró escéptico en el plenario: a ese tribunal le correspondería una cuota significativa de poder en virtud de la superintendencia disciplinaria sobre todos los tribunales de los territorios de la Corona. El señalaba que se había hecho un esfuerzo enorme por sentar las bases de la división de los poderes del Estado y entre ellos era el judicial el que siempre le había provocado resquemores. Fundamentaba lo anterior en que el legislativo trabajaba casi siempre en sesiones públicas; era una corporación numerosa; y sus miembros se encontraban sujetos a constante escrutinio de los ciudadanos y eran periódicamente renovados. Nada de eso pasaba en el poder judicial. El poder judicial estaba integrado por mucha gente dispersa a lo largo y ancho del territorio; sus miembros eran designados de por vida y su trabajo no era público. Ellos fallaban en privado. Era mucho más difícil para la ciudadanía controlarlos. Por ello manifestó su escepticismo ante la idea de contar con un Tribunal Supremo; pero más bien lo que le producía temor era el modelo organizativo en el que la comisión había pensado, pues creía que el mismo espíritu corporativo de los jueces como gremio impediría que este tribunal controlase de mejor manera el actuar de sus pares. Sus mayores objeciones decían relación con las facultades disciplinarias ${ }^{159}$. Correspondió a Fernández de Leiva explicar el punto al plenario de la Corte. Su argumentación fue muy simple y se centró en que perfectamente podrían establecerse tribunales supremos especiales en el futuro; pero que un tribunal supremo era sólo parte de las reformas que se planteaban en materia de judicatura y administración de justicia. Sobre la aplicación de las postestades disciplinarias que criticó el Conde de Toreno, Fernández de Leiva no pronunció palabra ${ }^{160}$.

Fernández fue el primero de los diputados en proponer que, dada la situación de emergencia y la necesidad de contar con hombres para la guerra, por una sola vez se conmutase la pena de muerte por la de destierro por el plazo de diez ańos para el caso de los delitos sancionados con dicha pena que no fuesen robo con reincidencia, asesinato y traición ${ }^{161}$. Dicha propuesta contó con el apoyó de algunos liberales; pero en definitiva no contó con los votos suficientes para su aprobación ${ }^{162}$.

158 Cortes Generales (1810 - 1813), op. cit. p. 1.169.

159 Estas críticas no son muy distintas a las que en Chile formula en ese mismo sentido Juan Egana en sus Cartas Pehuenches y en las que los sucesivos Ministros de Justicia en Chile en el período 1839-1870 denunciaron. Para mayor información véase WestermeYer Hernanández (2011), pp. 533-581.

160 Cortes Generales $(1810-1813)$, op. cit. p. 2.308.

161 Cortes Generales $(1810$ - 1813), op. cit. p. 129. Debe señalarse que en este punto no especifica cuales serían los delitos sujetos a la reforma y la calificación que se hace de los delitos exceptuados es muy vaga: ladrón famoso, muerte proditoria y traición.

162 Cortes Generales (1810 - 1813), op. cit. p. 130 
Desde la comisión de justicia le tocó resolver varios casos en que particulares se quejaban del actuar arbitrario de los organismos del estado. Es así como un sacerdote mexicano se quejó pues el Consejo de Indias no quería aplicar en su caso una ley de indulto, cabiendo su actuar perfectamente en las hipótesis que la ley establecía. Por esa razón argumentó que no procedía pedir informe al Consejo de Indias. Ellos eran los que habían aprobado ese indulto y como tal lo que correspondía era que tuviese aplicación inmediata ${ }^{163}$. Este y otros casos fueron convenciéndolo a él y a otros diputados acerca de la necesidad de una mayor reglamentación de la interpretación jurídica, pues en las deliberaciones en comisión y en pleno se escuchaba constantemente la queja que los tribunales torcían la voluntad emanada del legislativo mediante la interpretación ${ }^{164}$. Estaba conciente, asimismo, de que esa situación podría constituir también una vulneración del principio de la separación de los poderes del Estado. En su opinión, el principio de la separación de los poderes exigía la dictación de un estatuto para los detentarios de este oficio, con miras a asegurar la libertad de jueces y funcionarios judiciales y otorgarles la certeza acerca del ejercicio de sus funciones, obligaciones y derechos. Esa regulación limitaría el arbitrio judicial y así habría certeza respecto a quienes eran los que fallaban contra ley. Fernández de Leiva se declaraba enemigo de las leyes casuales. El creía que el "orden del Estado no debe esperar muchas leyes, sino que estas hagan costumbre" 165 .

Sus conocimientos de dogmática procesal penal eran de vanguardia. Con ocasión del proceso penal incoado contra el Marqués del Palacio, acusado de traición a la patria por haber prestado dos veces juramento de fidelidad, una ante las cortes pero otra ante el Monarca, la comisión de justicia estimó que debía ser absuelto pues el tribunal no fundamentó su condena ni tampoco explicaba los hechos que ameritaban dar curso al proceso. La condena se fundaba en una serie de presunciones pero en ningún hecho concreto. Por esas razones la comisión solicitó su absolución. Fernández de Leiva aprovecho la ocasión para dar rienda a sus conocimientos sobre derecho penal. Sostuvo que en su opinión se había ajustado a derecho iniciar un proceso pues hubo una denuncia y el tribunal estaba obligado a investigar cualquier hecho denunciado que tuviese caracteres de delito. Agregaba que era en ese momento y no antes cuando las partes tenían el derecho a ser escuchadas y a saber cuáles eran los cargos por los que se les imputaba. Sobre el caso en particular, señalaba que era también partidario de la absolución del procesado pues éste estuvo sometido a una enorme presión que lo privó de su sano juicio, y producto de ello había prestado juramento ante el Regente Interino; pero su irreprochable conducta y su trayectoria lo hacían merecedor de la absolución ${ }^{166}$.

163 Cortes Generales (1810 - 1813), op. cit. p. 235.

164 Cortes Generales $(1810$ - 1813), op. cit. p. 236. El diputado Valiente describe esta realidad, no obstante ser de opinión en el caso concreto de respetar al Consejo de Indias en aras de su prestigio y antigüedad.

165 Cortes Generales (1810 - 1813), op. cit. pp. 2.226-2.227. Palabras pronunciadas con ocasión de una discusión referente a la aplicación del decreto de abolición de los señoríos jurisdiccionales.

166 Cortes Generales (1810 - 1813), op. cit. p. 679. 
La última actuación en esta área en la que Fernández de Leiva participó fue en la presentación de un proyecto de reglamento para el otorgamiento de justicia en materia minera y mercantil. En el preámbulo la comisión reconoce que si bien las ideas en ese momento en boga propugnaban la derogación de todo tipo de fueros procesales, la existencia de esas dos justicias especiales se justifica en relación a la materia y a las normas procesales especiales que la praxis judicial había fundado. Es así como se reconoce en esas jurisdicciones el principio de la doble instancia, la existencia de jueces especiales, en este caso denominados diputaciones y la integración del juzgado de alzada por un juez letrado y dos peritos. Este conocerá los recursos que se interpongan ante el tribunal especial de minería y el único recurso de carácter extraordinario que se concederá será el de nulidad, el que será conocido por un tribunal especial integrado por el regente de la Audiencia competente y cuatro peritos de experticia en esos temas ${ }^{167}$.

La reforma a la jurisdicción mercantil tenía un contenido muy parecido, con la salvedad que los diputados tendrán competencia sólo en su ciudad o partido y serían designados por una junta de comerciantes. En primera instancia el tribunal competente sería el consulado en las capitales de provincia y sería la segunda instancia en las causas conocidas por los diputados. En el primero de los casos señalados, en caso de interponerse un recurso de apelación conocería el oidor decano de la Audiencia más dos adjuntos. Al igual que en la justicia minera, el único recurso extraordinario admisible era el de nulidad y sólo por la omisión de los requisitos que las ordenanzas del consulado declarasen esenciales ${ }^{168}$.

\section{La religión como factor determinante en el constitucionalismo gaditano}

Como ya se ha señalado, el contexto de reunión de las cortes es la invasión napoleónica y la necesidad de afirmar el sentimiento nacional en base a la tradición ${ }^{169}$. Por esa razón el juramento cumple un rol fundamental. La primera obligación de los diputados doceañistas era prestar el referido juramento. Como diputado suplente Fernández de Leiva debió prestarlo el primer día ${ }^{170}$. En esa ceremonia el presidente del Consejo de Regencia, Obispo de Orense, debía pronunciar una oración, luego de la que uno por uno, los diputados debían jurar la religión Católica, Apostólica y Romana, sin admitir ninguna otra creencia en los reinos que integraban la corona. Prestado ese juramento se procedía al segundo, mediante el cual los diputados se obligaban a conservar la integridad de la nación española y a no omitir medio alguno para su liberación. A

167 Cortes Generales $(1810-1813)$, op. cit. p. 2.882

168 Cortes Generales $(1810$ - 1813), op. cit. pp. 2.882-2.883.

169 En otro punto de este trabajo senalamos que el constitucionalismo es la culminación del desarrollo de la filosofía ilustrada, que por medio de esta expresión formula lleva a la norma sus intereses de reforma de la sociedad y las instituciones. También se indicó que este desarrollo filosófico tuvo peculiaridades en cada país europeo. En Espana en particular, siempre se lo intentó entroncar con el catolicismo, por lo que su versióin se denomina Ilustración Católica.

170 Cortes Generales (1810 - 1813), op. cit. p.2. 
continuación se juraba el respeto al monarca cautivo y a sus descendientes y por último se juraba desempańar fielmente el cargo encomendado: "guardando las leyes de España, sin perjuicio de alterar, moderar o variar aquellas que exigiese el bien de la nación” ${ }^{171}$. Este juramento refleja cuál sería el espíritu del trabajo legislativo y constituyente. Moderar, modificar pero siempre con dos límites, mantener la monarquía y resguardar la confesionalidad del Estado.

Una segunda manifestación de la importancia de la religión, como ya se vio, se dio a raíz del encabezado de la Constitución. El proyecto parte con una invocación: "En el nombre de Dios Todopoderoso, Padre, Hijo y Espíritu y Santo, autor y supremo Legislador de la Sociedad". Dicho encabezado fue en opinión de más de un diputado extremadamente conciso para lo que era la tradición hispana. Se le criticó no ser una profesión de fe, como si lo eran el Fuero Real, el Fuero Juzgo, Las Partidas, La Nueva Recopilación y la Novísima Recopilación ${ }^{172}$. De acuerdo a esa postura la fe cristiana necesariamente se debía expresar por medio de la profesión y el reconocimiento de los dogmas.

En esta discusión correspondió a Fernández de Leiva explicar ante el pleno cuál era la posición de la Comisión de Constitución. Para ello partió señalando que todos los miembros de la comisión eran católicos y que como tales creían que correspondía que el texto fuese encabezado por una advocación a la Santísima Trinidad, por considerarla el principio de todas las Instituciones. Sin embargo, no quisieron hacer una profesión de fe pues la detentadora de la potestad constituyente originaria es la nación y sólo a ella le correspondía hacer una declaración de fe. Esta se hacía en el texto por medio del artículo que reconocía la confesionalidad del Estado. La religión era uno de los elementos conformadores de la Nación Española. A través de ese artículo se consagraba la obligación de seguir los preceptos y enseñanzas de la Iglesia, bajo la dirección del romano Pontífice. Fernández era de la opinión que tal tratamiento implicaba de por si mantener a España en la ortodoxa católica y alejarla de cualquier otro credo. Por último, era de la opinión que quien profesaba la fe católica por ese sólo hecho estaba obligado a cumplir con lo planteado en los Concilios $^{173}$.

Esta presencia de la religión en el juramento y en la invocación a la Santísima Trinidad se explica por la idea que la creencia era en sí un freno a las ambiciones de poder. El compromiso de conciencia que implica la profesión de un credo religioso obliga a observar estándares de ética tanto en la esfera pública como en la privada ${ }^{174}$.

Sobre la relación Iglesia-Estado hubo durante la realización de las cortes importantes discusiones acerca de la posibilidad de que el fisco directamente se hiciese cargo de la mantención de eclesiásticos y sacerdotes y asumiese las responsabilidades y necesidades financieras de la Iglesia a cambio de poder entrar a disponer de sus numerosos bienes

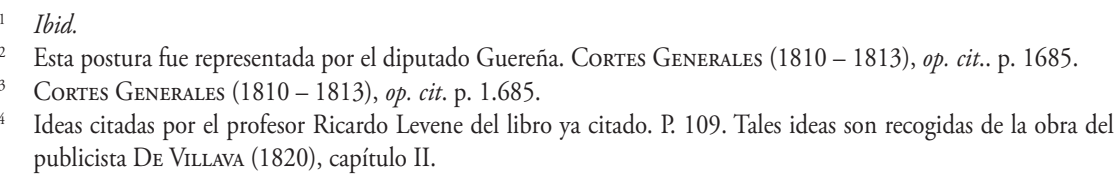


inmuebles y poder incorporarlos al tráfico jurídico, acabando con las manos muertas. Dicha labor fue ocupación preferente de la comisión de hacienda. En estas discusiones Fernández de Leiva no tomó parte.

Un aspecto curioso para su época fue su postura frente al regalismo. Con ocasión de discutirse la facultad del Consejo de Regencia de nombrar a todos los empleados civiles y eclesiásticos, el manifestó que los reyes no tenían ninguna atribución para designar a personas en cargos eclesiásticos. Sólo tenían el derecho a presentar; y era resorte exclusivo de la Iglesia decidir si aceptaba al presentado o no. No había obligación para la Iglesia. Por ello argumentó que el derecho de presentación era de una de las máximas regalías que poseía la Corona. Esta postura es bastante liberal respecto a la Iglesia, más aún viniendo de un jurista formado en la escuela regalista y en un ambiente cultural absolutamente inclinado hacia esas posturas ${ }^{175}$. Varios diputados encontraron razonable el argumento del chileno; sin embargo la discusión siguió otro rumbo, tendiente a determinar si en aras del principio de la separación de los poderes del Estado correspondería que las Cortes participasen en la designación y el nombramiento de un obispo o un arzobispo, por lo que en definitiva su postura no tuvo acogida en el texto constitucional ${ }^{176}$.

\section{Libertad de Imprenta:}

La religión jugó un rol muy importante al determinar la naturaleza y los fines de la Libertad de Imprenta. Los constituyentes la consideraban una pieza esencial del nuevo ordenamiento jurídico como el único medio para conocer el parecer de la opinión pública ${ }^{177}$, dirigir el debate y rectificar la labor de los diputados. También se tenía presente que la Religión y la libertad de imprenta estaban intrínsecamente relacionadas; pues las verdades de la religión eran infalibles y siempre triunfaban, por lo que la imprenta ayudaría a la divulgación de estas últimas. En ese sentido la libertad de imprenta es concebida como un coadyuvante de la educación y moralización de las masas y por ello un pilar del ordenamiento jurídico. Los menos dentro de las cortes entendieron la libertad de imprenta como un medio de control de la nación hacía sus gobernantes y por ello, como una institución de carácter secular. Los diputados consideraban que la libertad se basaba en dos pilares: la separación de los poderes del estado y la libertad de imprenta; pero esta última no tenía el carácter de un derecho fundamental. Se la entendía como un medio de educación y moralización. Sobre esta última posición, luminosas son las palabras del diputado suplente argentino Francisco

175 El regalismo entendía que era decisión de la monarquía decidir y nombrar a los eclesiásticos. La Santa Sede era informada una vez que el escogido por el poder real asumía el cargo. Cortes Generales (1810 - 1813), op. cit. p.205

176 Cortes Generales $(1810$ - 1813), op. cit. p.206-207

177 Se pensaba que a través de la opinión pública se podía determinar cuál era la voluntad de la nación. 
Lisperguer ${ }^{178}$, quien sostuvo: "nada hace al hombre más estúpido y pacato que la opresión y la injusticia, y; nada hace triunfar más el despotismo como el mantener a los pueblos en la ignorancia." ${ }^{179}$.

En esta discusión Fernández de Leiva tomó parte como jurista, manifestando algunas aprensiones con la manera en que el proyecto de ley estaba redactado ${ }^{180}$.

La concepción de libertad de imprenta que poseían los diputados doceañistas era muy restringida. Se limitaba a la libertad para escribir, publicar e imprimir ideas políticas sin necesidad de revisión o aprobación. Ahora el control sería a posteriori y quedaba en manos de los tribunales. En los hechos esta nueva normativa implicó su abolición. De todas formas estaba iguialmente prohibido calumniar y discutirse sobre las leyes fundamentales de la Monarquía ni atentar contra la decencia pública ${ }^{181}$. El hecho de concebírsela como un medio de moralización de las masas autorizaba la existencia de una serie de medios de control de lo impreso y una amplia restricción en base a la moral pública y a la religión. El investigado manifestó en más de una ocasión su conformidad con ciertas restricciones por considerar que los escritos dañaban la moral cristiana ${ }^{182}$.

Sólo a modo de ejemplo, con ocasión de la publicación del periódico "La Triple Alianza”, el Consejo de Regencia optó por denunciar la publicación al Tribunal del Santo Oficio por considerar que contenía expresiones que iban contra la moral cristiana. Dicha situación fue conocida y discutida por las Cortes, las que estimaron que todo se ajustaba a derecho ${ }^{183}$.

\section{Algunas coincidencias entre las ideas de Joaquín Fernández de Leiva y las ideas postuladas en Chile entre 1810 y 1814}

Responder la pregunta acerca de la correspondencia entre las ideas defendidas por Fernández de leiva en Cádiz y las vigentes en Chile durante el período conocido como patria vieja (1810-1814) obliga a buscar las obras más elaboradas que durante esos anos tuvieron divulgación en Chile. Mediante un estudio acerca de la eventual coincidencia entre los postulados que el reivindicó en Cádiz y los vigentes en Chile podemos aventurar si efectivamente este medio hermano de Manuel Rodríguez fue un pionero o si sus ideas eran compartidas por otros sectores de la sociedad chilena. Para estos efectos no deja de ser significativo que, en comparación con otros movimientos juntistas, en el chileno el sentimiento independentista tuvo un desarrollo bastante

\footnotetext{
178 También conocido como Francisco López Lisperguer. De marcado carácter conservador, se opuso a la abolición de los senoríos y partidario de una regencia por parte de la Infanta Carlota Joaquina, reina consorte de Portugal.

179 Cortes Generales (1810 - 1813), op. cit. p. 432.

180 Cortes Generales $(1810$ - 1813), op. cit. p. 50.

181 Cortes Generales $(1810-1813)$, op. cit. p.54.

182 Cortes Generales $(1810$ - 1813), op. cit. p. 450 .

183 Cortes Generales $(1810$ - 1813), op. cit. p. 469 y siguientes.
} 
más lento ${ }^{184}$. Tal es la razón por la que los textos jurídicos que tuvieron vigencia son en términos ideológicos relativamente neutros y de escaso desarrollo dogmático. Tales textos fueron el reglamento constitucional de 1811 y el reglamento constitucional de 1812. El primero de ellos conserva un lenguaje indiano, aunque introduce elementos propios del constitucionalismo. Parte reconociendo que Chile es un reino y que su principal motor es la división de los poderes del Estado. El poder más importante en este documento es el legislativo, personificado en un congreso nacional, quien es el único depositario de la voluntad del reino. A él le correspondía la apertura de la correspondencia de relevncia diplomática, delagra el mando de las fuerzas armadas, regular el funcionamiento de las fuerzas armadas, la creación, supresión, nombramiento y modifcaciones de la planta de la administración pública. Por esa razón el ejecutivo debería consultar con el congreso las designaciones en la administración pública. En resumen, cabe senalar que el tenor de las discusiones fue casi el mismo que el que hubo en Cádiz, aunque las soluciones zanjadas fueron por derroteros distintos.

El reglamento constitucional de 1812 posee una elaboración un poco mejor. Parte con un reconocimiento del carácter confesional del Estado y en su artículo $3^{\circ}$ reconoce a Fernando VII como rey de Chile, "quien aceptará nuestra constitución del mismo modo que la de la península”. En este punto queda claro que los redactores estaban al tanto del proceso vivido en Cádiz que utilizan el argumento de la pepa como justificación para sus pretensiones autonomistas. La constitución debía ser elaborada por los representantes de la voluntad general, aunque no menciona a la nación como detentadora de la potestad constituyente. El organismo constitucional más importante es el senado, quien tenía a su cargo los "negocios graves".

Asimismo, este reglamento introduce por primera vez garantías de carácter procesal penal, como por ejemplo la obligación de jueces y tribunales de fallar de acuerdo a la legislación vigente, la libertad ambulatoria como un derecho que sólo puede ser restringido habiendo sospechas fehacientes de delito y la incomunicación como medida que no podía superar el plazo de 10 días. En cuanto a la libertad de imprenta, este reglamento también le cponfirió un carácter restringido, pues en ningún caso podía derivar en "licencia nociva a la religión, costumbre y honor de los ciudadanos". Finalmente, el artículo 24 comnsagró el mérito como elemento fundamental en la vida cívica.

Si bien ambos textos trasuntan ideas de corte político y jurídico, durante el período que va de 1810 a 1814 hay dos documentos que reflejan de mejor manera la sensibilidad política y jurídica de una parte de la elite y uno de carácter ilustrativo y de énfasis político, de gran circulación en esos días. Tales son el proyecto constitucional de 1811, la "Declaración de los Derechos del Pueblo de Chile"185 y el tercero es el catecismo político

\footnotetext{
184 Mientras la declaración de Independencia de Chile fue el 12 de febrero de 1818, la de Venezuela tuvo lugar el 5 de julio de 1811, en Cundinamarca el 15 de julio del mismo ano; en Cartagena el 11 de septiembre de 1811; en Quito el 11 de octubre de ese mismo ano. Dos ańos después sería el turno de México mediante el congreso de Chilpancingo, de Paraguay el 12 de octubre y del Virreinato de la Plata el 31 de Enero.

185 Letelier (1886 - 1908), pp. 209 y siguientes
} 
cristiano. Los dos primeros fueron redactados por encargo del Congreso Nacional. Dicha responsabilidad recayó en Juan Egana, Manuel de Salas, Joaquín Larraín y Juan José Echevarría. Dicho encargo tuvo lugar el ano 1811; pero la contingencia política y la aparición de José Miguel Carrera dejaron este proyecto casi dos anos en tabla. Hasta que la nueva junta de gobierno, el ano 1813, decretó su publicación a fin de facilitar el debate y la discusión.

De la lectura de ambos textos se desprende que los comisionados estuvieron lejos de alcanzar el nivel de fineza y elaboración jurídica al que se llegó en la Cádiz. Eso no quita que los "principios liberales" orientaron a ese grupo. Ellos explicitan la intención de formar un congreso que reúna a la nación espanola; hacen hincapié en la preeminencia de la constitución por sobre la figura del monarca y el derecho a buscar una forma de gobierno que sea respetada por Fernando VII. En otras palabras, también existía la esperanza de reformar el sistema manteniendo la forma de gobierno monárquica y supranacional. Tales documentos supeditaban la figura del monarca a la nación y preservaban el derecho de esta a determinar la forma de gobierno que considerase más adecuada.

Este proyecto de constitución es muy similar en cuanto a principios a la Pepa. Se consagraba la confesionalidad del Estado; se menciona a la divinidad en su forma trinitaria. Se consagró también el principio de igualdad, desde el mismo momento del nacimiento; la igualdad de todos ante la ley (art. 27 y art. 28) y el sistema de castas fue expresamente abolido (art. 78).

La igualdad a su vez era contenida en base a la virtud. Dicha institución fue conocida en el primer constitucionalismo patrio como "Mérito." Meritorio era el que sabía leer y escribir, estaba instruído en las leyes de la vida social y realizaba actividades en beneficio de la sociedad. De acuerdo al artículo 68 del proyecto de constitución actividad en beneficio de la sociedad era el ejercicio de una profesión u oficio.

Sobre este punto, es importante destacar que gran parte de la historia constitucional chilena ha hecho un análisis de las normas constitucionales sobre ciudadanía vigentes a lo largo del siglo XIX desde un punto de vista exclusivamente sociológico y/o electoral, mas nadie ha reparado en que todas ellas se basan en una dogmática constitucional muy propia y característica del siglo XIX. Creemos que parte de esta omisión se puede explicar por la excesiva reglamentación que Juan Egana dio a este instituto en el proyecto de 1811 y en la constitución de $1823^{186}$. En ambos textos el mérito es uno de los pilares del edificio constitucional, teniendo tanta importancia como la institución a la que servía de pilar: la ciudadanía. Los textos posteriores también recogieron la idea de mérito, como la constitución de 1828 en su artículo $7^{\circ} \mathrm{N}^{\circ} 1$ y la constitucion de 1833 en su artículo $8 \mathrm{~N}^{\circ} 2$, aunque esta última tenía una concepción de mérito bastante más restringida que aquella que círculó durante la patria vieja.

186 Hacemos referencia a Egana pues gran parte de los puntos que el desarrolló en sus proyectos constitucionales han sido sistemáticamente desvalorados. Para una mejor apreciación de esa situación véase Westermeyer Hernández (2011), pp. 169-202. 
En cuanto a administración de justicia, también en este proyecto se pueden observar una serie de coincidencias con la Pepa. Lo más importante es el reconocimiento de una serie de garantías: presunción de inocencia, sentido rehabilitante de la pena, proporcionalidad entre delito y pena asignada; prohibición de la tortura, inmediación del tribunal, inviolabilidad del domicilio y la correspondencia, prohibición de encarcelar sin documento fehaciente de la autoridad competente y derecho a ser juzgado por un tribunal previamente constituído por ley.

De una simple comparación de las ideas generales de ambos textos del derecho patrio con lo contenido en las actas de las Cortes pareciera ser muy claro que las ideas que reivindicó Joaquín Fernández de Leiva eran compartidas por sectores ilustrados de la clase dirigente nacional. En ese sentido Fernández de Leiva descolló en Cádiz por su oratoria, hábil manejo del debate y conocimientos, mas no se puede afirmar que sus ideas fuesen excéntricas entre los círculos ilustrados el Chile de la Patria Vieja.

En cuanto al catecismo político-cristiano, cuya autoría es desconocida, pues estaba redactado con el seudónimo de José Amor de la Patria, este exhibe una postura muy crítica frente a las cortes de cádiz. Su postura se basa en la subrepresentación de los reinos americanos, siendo que en ellos habitaban más de la mitad de los subditos de la Corona manifiesta desconfianza ante el proyecto constitucional de cádiz en aras de las necesidades económicas que traía a la oposición la guerra contra Napoleón. Creía que sólo la necesidad de contar con recursos económicos motivaba la invitación al proceso constituyente.

El autor hace hincapié en que la "fidelidad monárquica" estaba condicionada a la venida a América de Fernando VII, y a que respetase la constitución que estas tierras se darían. En cuanto a la igualdad, este manifiesto la trata a raíz de la explicación del concepto de república; pero no procede a explicarla. A ese respecto Walter Hanisch plantea que Fernández de Leiva sostuvo en sus discursos una idea muy semejante a la que se desprende de ese opúsculo ${ }^{187}$. Dicha obra no posee una elaboración muy detallada respecto a las distintas formas de gobierno; pero destaca que entre ellas la mejor es la republicana., entendiéndola como el gobierno plural de unos diputados o una junta, elegidos de manera periódica ${ }^{188}$. En este punto también se puede apreciar parcialmente una coincidencia con las ideas planteadas por el chileno en cádiz. Para él la mejor forma de darle legitimidad a un gobierno monárquico era que los gobiernos locales, representantes del monarca, tuviesen un carácter colegiado, para así evitar la discrecionalidad y el despotismo.

En cuanto al detentador de la soberanía, José Amor de la Patria sostiene que la potestad constituyente original se encuentra en el pueblo y como tal, este tiene todo el derecho de cambiar la forma de gobierno en la medida en que se encuentre otra que

187 Hanisch (1970), p. 33

188 Dice el texto: "El gobierno republicano, el democrático en que manda el pueblo, por medio de sus representantes o diputados que elige, es el único que conserva la dignidad y mejestad del pueblo..." Asimismo véase Hanisch (1970), op.cit., p. 34 
corresponda de mejor manera con la felicidad común. Curiosamente esta idea, felicidad común, constituye el criterio para distinguir el buen gobierno del malo y por ello, la no consecución de esos fines permitiría la deposición del gobernante e inclusive el cambio de sistema de gobierno: "Cuando los pueblos han instituido un gobierno, sea Monárquico o Republicano... lo han instituido en beneficio del Pueblo y para hacer su dicha. El Pueblo que ha conferido a los Reyes el poder de mandar, puede, como todo poderdante, revocar los poderes y nombrar otros guardianes que mejor correspondan a la felicidad común. Si el rey es un inepto, es un malvado o un tirano para creer que los hombvres en la institución de los gobiernos no se han reservado este derecho sagrado, imprescriptible e inajenable y tan necesario para su felicidad, era precuiso suponer a que todos estan locos, que todos eran estúpidos, o mentecatos; por la misma razón pueden alterrar la forma de gobierno una vez establecida, por justas y graves causas, siempre que esto sea conveniente a la utilidad y provecho de los pueblos" 189 .

Importa destacar que si bien en este punto Fernández de Leiva no hizo ninguna exposición doctrinal, podría interpretarse que su interés porque entre los objetivos del gobierno estuviese la felicidad pública como una menra de mantener en pie ciertos criterios de raigambre en la tradición jurídica hispana y en el derecho indiano ${ }^{190}$.

Un punto de diferencia se da sobre la idea de nación. Fernández de Leiva habló siempre de la nación espanola mientras José Amor de la Patria sólo de un congreso general de americanos. "Convocad carísimos hermanos un cabildo abierto, formado por vosotros mismos, en caso necesario, y allí hablad, acordad y decidid acerca de vuestra futura suerte con la energía y dignidad de hombres libres:... formad desde luego una junta provisional, que se encargue del mando superior y convocar los diputados del reino para que hagan su constitución y su dicha: el congreso general, la representación nacional de todas las provincias de América meridional..."

Sobre la virtud, el catecismo político-cristiano, no dice nada.

Finalmente, se puede senalar que entre las ideas expuestas por Fernández de Leiva y el autor de este opúsculo hay algunas coincidencias, pero no debe olvidarse que este era un pasquín de batalla cuyo objetivo era incentivar el debate político. No deja de ser interesante que hay un consenso en torno a la división del poder, a la necesidad que el monarca reconozca la o las nuevas constitucionesy en cuanto a las críticas y motivos para desconfiar de la asamblea constituyente de Cádiz, estas no pasaron inadvertidas para Fernández de Leiva, sino que, por el contrario, las hizo oír directamente en los plenarios.

Por estos motivos podemos concluir que las ideas de Fernández de Leiva fueron todo menos peregrinas. Sólo llevó a un foro internacional las ideas por otros también compartidas en Chile.

189 Texto del manuscrito obtenido del sitio web www.memoriachilena.cl la ortografía fue adaptada a las reglas vigentes hoy en día.

190 En este punto Walter Hanisch sostiene que la reversión de los poderes por parte del pueblo era doctrina común entre los doctores escolásticos. Hanisch (1970), op.cit., p.39. 


\section{Consideraciones finales:}

1. Joaquín Fernández de Leiva fue un jurista formado completamente en Chile, al alero de la Real Universidad de San Felipe, con un importante reconocimiento entre los estudiosos de la Constitución de Cádiz.

2. Fernández de Leiva es el jurista chileno de la época indiana que tuvo más vitrina a nivel internacional. Su participación en las Cortes de Cádiz lo contactó con hombres de derecho de todos los rincones de habla hispana. En las Cortes destacó por su formación jurídica, por lo que lo denominamos como el jurista epónimo del Chile indiano.

3. Esta situación muestra como al cabo de cincuenta anos de estudios de derecho en Chile, la cultura jurídica universitaria nacional ya estaba en condiciones de formar profesionales de elite, con sólidos conocimientos acerca de las corrientes y tendencias jurídicas en ese momento en boga.

4. Si bien acorde a su designación clasifica como diputado suplente por el reino de Chile, el viajó a Espana con un mandato de corte jurídico y político; por lo que si bien el Cabildo de Santiago no lo designa como diputado constituyente, no se puede desconocer que el desempeno de esa labor podría haberse previsto dentro de su mandato.

5. De acuerdo al informe emitido por José Miguel Infante acerca de quiénes son los que pueden actuar como soberanos a nombre del reino en ausencia del rey, Fernández de Leiva podría ser considerado detentatario de un poder soberano del reino de Chile.

6. Dentro de las distintas facciones que a lo largo del trabajo de las Cortes se fueron formando, siempre tuvo dos domicilios indiscutidos: liberal y americanista, aunque no todos están de acuerdo en considerarlo un patriota.

7. El acervo jurídico que llevó Fernández de Leiva no difería sustancialmente de aquel que varios hombres de derecho en Chile en ese momento tenían. La idea de una monarquía constitucional, un monarca supeditado a la nación y una nueva constelación entre los principios de igualdad y representación política se manifiestan en Chile de manera similar entre 1810 y 1814 cómo ocurrió en Cádiz. Eas ideas fueron los ejes de su trabajo en las Cortes de Cádiz, así como también la fundación de una nueva institucionalidad basada en el principio de la división de los Poderes del Estado y una mejor administración de justicia.

8. Es destacable el realismo y prudencia con el que actuó el investigado en relación al proceso de legitimación y promulgación de la Pepa.

9. Adhiere a lo que se ha llamado ilustración católica. Buscó compatibilizar la fe con la nueva filosofía. Buscó una permanente cooperación entre el poder temporal y el perpetuo. Tal situación explica que no hubiese concebido la libertad de imprenta como un derecho fundamental y que fuese partidario de la confesionalidad del Estado. 
10. Llamativa resulta su postura frente al derecho de presentación y al regalismo. Su posición por la independencia y una mayor libertad de la Iglesia frente al poder político es poco comunes en ese período.

11. Pese a las posibles razones de conveniencia política e ideológica que pueden explicar su permanente omisión por parte de la historia de Chile, es importante rescatar su figura como un jurista que jugó un papel relevante en la redacción de una carta fundamental de primera importancia en latinoamérica y en la discusión de importantes reformas legales que buscaron implementar las reformas propuestas por los pensadores ilustrados. Su labor como orador, redactor, jurista y, por qué no decirlo, ideólogo y político le dan una importancia que sólo ha sido justamente reconocida, por cultores extranjeros de la historia del derecho y el derecho constitucional.

12. Quizás, en base al estudio de personas como Joaquín Fernández de Leiva, sería oportuno replantear el rol que se le reconoce en nuestra historia a la Real Universidad de San Felipe. Hombres como el susodicho muestran que también fue un faro de luz, ilustración y libertad.

13. Oportuno resultaría plantear, a la luz de las nuevas interpretaciones sobre el constitucionalismo gaditano, qué fue el derecho constitucional como disciplina jurídica en el siglo XVIII y la primera década del siglo XIX. Lo acaecido en Chile y en Cádiz muestra que el derecho constitucional llegó a América y fue recepcionado por los juristas mucho antes que las constituciones escritas. En este punto no sólo es importante tener presente que dicha rama del derecho fue la encargada de llevar a terminología jurídica muchos de los cambios sociales acaecidos en el siglo XIX. Tampoco basta con considerar que el campo de acción del derecho constitucional fue mucho más vasto que el que posee en el siglo XX, sino que también sería oportuno ir un poco más allá y hablar de una suerte de polifonía constitucional en ese tiempo. En Chile no hubo una sólo una concepción constitucional. El constitucionalismo chileno no sólo tuvo una versión republicana y liberal. También hubo voces que propugnaron una monarquía constitucional y -aunque escapa a este artículo- puede que también haya habido otros cuya visión tuviese un mayor acento en aspectos sociales.

\section{Referencias Bibliográficas}

ALCAUTER GUZMÁN, JosÉ LuIs (2012): Régimen de Subdelegaciones en la América Borobónica. Autoridades Intermedias en transición, Valladolid de Michoacán Tesis para Optar al Grado de Doctor en ciencias Humanas. Colegio de Michoacán, Centro de Estudios de las Tradiciones, México. Texto disponible en sitio web www.colmich.edu.mx.

BARRIENTOS GRANDÓN, Javier (2011): "La Constitución de Cádiz en Chile" en Cortes y Constitución de Cádiz. 200 años. Dirección. José Antonio Escudero. Tomo III. Fundación Rafael del Pino, España. 
BERRUEZO, María Teresa (1986): La participación Americana en las Cortes de Cádiz (1810-1814). Centro de Estudios Constitucionales, Madrid.

CAFFARENA BARCENILla, Paula (2012): Las Cortes de Cádizy Chile: Encuentros y desenecuentrosa partir de sus diputados Joaquín Fernández de Leiva y Miguel Riesco. En: Historia, $\mathrm{N}^{\circ} 396$, Vol II, $\mathrm{N}^{\circ} 2$, pp. 223 - 244. Texto disponible en internet, sitio www.dialnet.unirioja.es

CONDE DE TORENO (1872): Historia del Levantamiento, Guerra y Revolución en España. Imprenta Rivadeyneira. Madrid.

CORTES GENERALES (1810 - 1813): Diario de las Sesiones de las Cortes Generales y Extraordinarias, Cádiz.

DOUGNAC RODRÍGUEZ, Antonio (I999): "Proyección de las Ordenanzas de Minería de Nueva España en Chile (1787-1874)” En: Revista de Estudios Histórico Jurídicos. № 21 Pontificia Universidad Católica de Valparaíso, pp.111-158.

DE VILLAVA, VICTORIÁN (I820): Apuntes para una reforma en España, sin trastorno del Gobierno Monárquico ni de la Religión, Buenos Aires.

ESTRADA MICHEL, Rafael (2010): Nación y Constitución en 1812. Editorial Porrúa, México.

EYZAGUIRRE, Jaime (1996): Ideario y ruta de la Emancipación Chilena. Editorial Universitaria. $24^{\circ}$ edición, Santiago de Chile.

GALDAMES, Luis (1992): Historia Constitucional de Chile. Editorial Jurídica de Chile, Santiago.

GARCÍA HUIDOBRO, ElÍAs (I9I2): "Las Cortes de Cádiz y las elecciones de los diputados de Chile”. En: Revista Chilena de Historia y Geografía. Volumen IV, p.330-361, Santiago de Chile.

HANISCH ESPÍNDOLA, Hugo (1970): El catecismo politico cristiano. Las ideas y la época. 1810. Editorial Andrés Bello, Santiago de Chile.

HANISCH, Walter (1970): El catecismo politico-cristiano. Las ideas y la época. 1810. Editorial Andrés Bello, Santiago de Chile.

LETELIER, VALENTÍN (compilador) (1886 - 1908): Sesiones de los cuerpos legislativos de la República de Chile (1811-1845), Imprenta Cervantes, Santiago de Chile.

LEVENE, Ricardo (1956): El mundo de las ideas y la Revolución Hispanoamericana de 1810. Editorial Jurídica de Chile, Santiago de Chile.

LOHMAN VILlENA, Guillermo (1974): Los Ministros de la Audiencia de Lima en el reinado de los Borbones. Escuela de Estudios Hispanoamericanos, Sevilla.

MATTA VIAL, Enrique (I920): "El diputado de Chile en las Cortes de Cádiz, don Joaquín Fernández de Leiva" En: Revista Chilena de Historia y Geografía. N ${ }^{\circ}$ 37-38, pp. 307-340, Santiago de Chile. 
MEZA VILLALOBOS, Néstor (1956): La actividad politica del Reino de Chile entre 1806-1810. Facultad de Filosofía y Educación. Universidad de Chile. Editorial Universitaria, Santiago.

MEZA VILLALOBOS, NÉSTOR (1958): La conciencia politica chilena durante la monarquía. Instituto de Investigaciones Histórico-Culturales. Facultad de filosofía y Educación. Universidad de Chile. Editorial Universitaria, Santiago de Chile.

PACHECO, Toribio (1954): Cuestiones Constitucionales. Arequipa. Imprenta de Francisco Ibañez.

PORRAS RAMÍREZ, JosÉ María (20I3): “La Federación Imposible. El proyecto constitucional americano en las Cortes de Cádiz”. En: Revista de Estudios Constitucionales Volumen $11 \mathrm{~N}^{\circ}$ 1, Santiago de Chile.

ROZAS, RAmón (1885): “El embajador de Chile en España en 1808” en Revista de Artes y Letras. Volumen V, p. 32 y siguientes, Santiago.

SANCHEZ - ARCHILLA BERNAL, José (1988): "La aportación de los diputados de la Nueva Espana a las Cortes de Cádiz: Mariano Mendiola”.en: Memoria del IV Congreso de Historia del Derecho Mexicano, Universidad Autónoma de México, Instituto de Investigaciones Jurídicas, México.

SANTOS CORONAS, Manuel (2004): "La Trayectoria del Conde de Toreno: Del liberalismo revolucionario al liberalismo conservador". En: Historia Constitucional. Revista electrónica. $\mathrm{N}^{\circ} 5$. Sitio web www.historiaconstitucional.com

URQUIJO, José María Mariluz (2008): "Historia de las Ideas Jurídicas del Setecientos Rioplatense. Problema de una Investigación" en: Homenaje a Alberto de la Hera. Rosa María Martínez de Codes y Jose Luis Soberanes Fernández. Editores. Universidad Nacional Autónoma de México, México.

WESTERMEYER HERNÁNDEZ, FeLIPe (20II): "Derecho indiano y Derecho patrio en las memorias de los ministros de justicia en Chile" en: Revista de Estudios Histórico Jurídicos. N³3. Pontificia Universidad Católica de Valparaíso, pp. 533-581.

WESTERMEYER HERNÁNDEZ, Felipe (2011): "Notas para el Estudio del pensamiento jurídico conservador de Juan Egańa” en: Revista de Derecho y Humanidades $\mathrm{N}^{\circ} 17$. pp. 169-202.

WESTERMEYER HERNÁNDEZ, FeLIPE (20I2): "Chile y la Constitución de Cádiz: un primer acercamiento a una relación preterida” en: Cuando Las Cortes de Cádiz. Panorama jurídico 1812. Jornada Conmemorativa del Bicentenario. Coordinador Luis Martí Mingarro. Universidad Nacional Autónoma de México. Instituto de Investigaciones Jurídicas, México.

WESTERMEYER HERNÁNDEZ, Felipe (20I4): "La Constitución de Cádiz de 1812 y su influencia en el devenir constitucional chileno", en: Revista de Derecho Público N ${ }^{\circ} 79$. Departamento de Derecho Público. Facultad de Derecho Universidad de Chile, Santiago 